\title{
In vivo discovery of RNA proximal proteins in human cells via
}

3 Xianzhi $\operatorname{Lin}^{1,2 *}$, Marcos A. S. Fonseca ${ }^{1,2}$, Rosario I. Corona ${ }^{1,2}$, Kate Lawrenson ${ }^{1,2,3 *}$

$5 \quad{ }^{1}$ Women's Cancer Research Program at Samuel Oschin Comprehensive Cancer Institute,

6 Cedars-Sinai Medical Center, Los Angeles, CA, USA.

7 2Division of Gynecologic Oncology, Department of Obstetrics and Gynecology, Cedars-

8 Sinai Medical Center, Los Angeles, CA, USA.

$9 \quad{ }^{3}$ Center for Bioinformatics and Functional Genomics, Samuel Oschin Comprehensive

10 Cancer Institute, Cedars-Sinai Medical Center, Los Angeles, CA, USA.

$11{ }^{*}$ Correspondence: xianzhi.lin@cshs.org (X.L.) or kate.lawrenson@cshs.org (K.L.) 


\section{Abstract}

15 RNA molecules function as messengers or noncoding adaptor molecules, structural components, and regulators of genome organization and gene expression. Their roles and regulation are mediated by other molecules they interact with, especially RNA binding proteins (RBPs). Here we report RNA proximity labeling (RPL), an RNA-centric method based on fusion of an endonuclease-deficient Type VI CRISPR-Cas protein (dCas13b) and engineered ascorbate peroxidase (APEX2) to discover in vivo target RNA proximal

21 proteins (RPPs) through proximity-based biotinylation. U1 RPPs enriched by proximitybased biotinylation included both $U 1$ snRNA canonical and noncanonical functionsrelated proteins. In addition, profiling of poly $(\mathrm{A})$ tail proximal proteins uncovered expected

24 categories of RBPs for poly $(A)$ tails and also provided novel evidence for poly $(A)^{+}$RNA rapid approach for identifying both interacting and neighboring proteins associated with target RNA molecules in their native cellular contexts.

\section{Keywords}

30 Type VI CRISPR-Cas (Cas13), Engineered soybean ascorbate peroxidase APEX2,

31 Proximity-dependent biotinylation, RNA proximity labeling (RPL), RNA proximal proteins

32 (RPPs), RNA-centric method, RNA-protein interactions, poly(A) tail, RNA binding proteins 33 (RBPs), U1 snRNA interactors. 
Introduction

RNA molecules include both messengers encoding proteins (mRNAs) and noncoding RNAs (ncRNAs) such as adaptor tRNAs and regulatory long noncoding RNAs (IncRNAs). transcribed into ncRNAs (Berretta and Morillon, 2009; Djebali et al., 2012), including IncRNAs that are widely considered as a large family of potential regulators (Batista and

42 Chang, 2013; lyer et al., 2015; Yang et al., 2014). However, only a small number of 43 IncRNAs have been functionally and mechanistically studied and most remain uncharacterized (Kopp and Mendell, 2018).

45 The functions and regulation of RNA transcripts are mediated by other molecules they associate with, particularly RNA binding proteins (RBPs) that govern many critical RNA

47 activities (Dreyfuss et al., 2002; Glisovic et al., 2008; Hentze et al., 2018; Lunde et al., 2007). Discovery of the interacting proteins for a given transcript plays pivotal role in unveiling its function and underlying mechanism. Currently, mechanistic study of IncRNAs

50 is impeded by the shortage of RNA-centric tools and the limitations of existing methods

51 (Ci Chu et al., 2015; Ramanathan et al., 2019). Antisense probe-based ChIRP (C. Chu 52 et al., 2015) or RAP (McHugh et al., 2015) requires crosslinking via chemicals or UV 53 light. However, chemicals such as formaldehyde also crosslink protein-protein 54 interactions, which may lead to false-positive associations (Panhale et al., 2019). Since UV-crosslinking has very low efficiency, antisense probe-based purification methods 56 usually require a large number of cells ( 100-800 million) (Lin et al., 2019; McHugh et 57 al., 2015), which may not be feasible for slow-growing model systems such as primary 
58 cell cultures. Moreover, UV-crosslinking can induce RNA alterations like modifications

59 (Wurtmann and Wolin, 2009) that could change binding affinity of RNA to certain RBPs

60 (Bernard et al., 2012) and impair downstream protein analysis (Urdaneta and

61 Beckmann, 2019). An alternative approach, tagging of endogenous RNA requires

62 genetic manipulation and may interfere with endogenous RNA functions (Laprade et al.,

63 2020). Therefore, methods to discover endogenous RNA interacting proteins are needed.

64 In this study, we developed RPL (RNA proximity labelling) method to identify in vivo

65 target RNA proximal proteins (RPPs) without crosslinking or genetic manipulation. U1

66 RPPs recalled $U 1$ functional relevant proteins, while poly $(A)$ tail RPPs recalled expected

67 categories of RBPs for poly $(A)$ tails providing additional evidence for poly $(A)^{+} R^{2} A 5^{\prime}-3^{\prime}$

68 proximity and expanded subcellular localizations.

69 


\section{Results}

71 Design and development of RPL, an RNA-centric method for screening RPPs

72 Inspired by the applications of RNA-targeting Type VI CRISPR-Cas systems (Abudayyeh

73 et al., 2017;, Cox et al., 2017;, Konermann et al., 2018; Yan et al., 2018) and proximity

74 labeling using engineered soybean ascorbate peroxidase (Lam et al., 2015; Rhee et al.,

75 2013) and biotin ligase (Branon et al., 2018; Kim et al., 2016; Roux et al., 2012), we

76 designed RPL, an RNA-centric approach based on a fusion protein of endonuclease-

77 deficient Cas13 (dCas13) and proximity labeling enzyme APEX2 (Figure 1A). The fusion

78 protein is directed to target RNA by a sequence-specific guide RNA (gRNA). In the

79 presence of hydrogen peroxide $\left(\mathrm{H}_{2} \mathrm{O}_{2}\right)$, APEX2 in the fusion protein oxidizes substrate

80 biotin-phenol (BP) to short-lived biotin-phenoxyl radicals, which covalently react with

81 electron-rich amino acids (like tyrosine) on RPPs within a small radius (Rhee et al., 2013)

82 of the fusion protein (Figure 1A). The biotinylated RPPs, which may include target RNA

83 direct binding proteins, indirect binding proteins, and proximal proteins just present within

84 biotinylating radius, can be readily enriched using streptavidin beads and profiled by liquid chromatography-tandem mass spectrometry (LC-MS/MS) (Figure 1A).

To construct the fusion protein, Cas13b was used for its high efficacy in RNA

87 knockdown with minimal off-target effect (Cox et al., 2017) and high specificity in RNA

88 labeling (Yang et al., 2019). For proximity labeling enzyme, we chose APEX2 for its fast

89 kinetics and high activity (Lam et al., 2015). Catalytically dead Cas13b from Prevotella

90 sp. P5-125 (dPspCas13b) (Cox et al., 2017) was fused to APEX2 with FLAG and HA

91 tags (Figure 1B). The expression of the fusion protein dCas13b-APEX2 (from hereon in

92 called the RPL protein) was confirmed by western blot using an anti-FLAG or anti-HA 
A

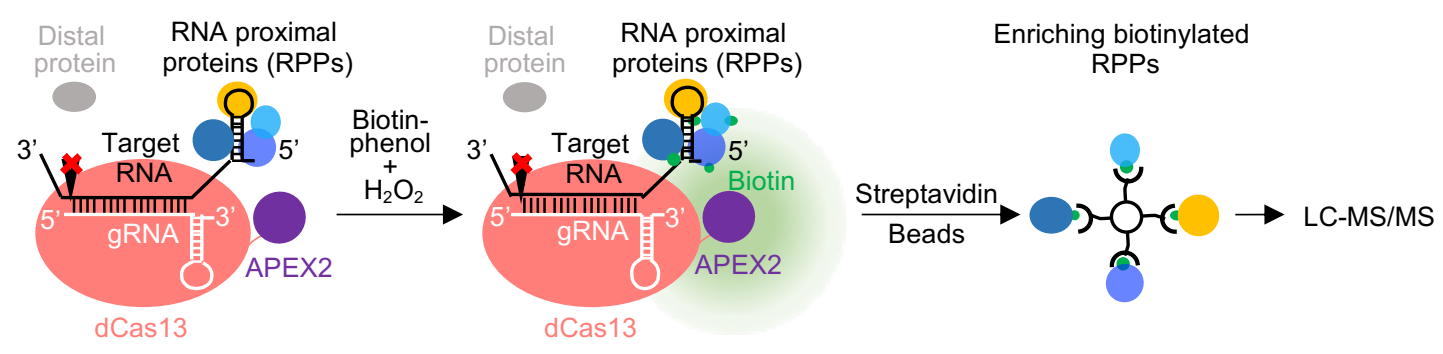

B

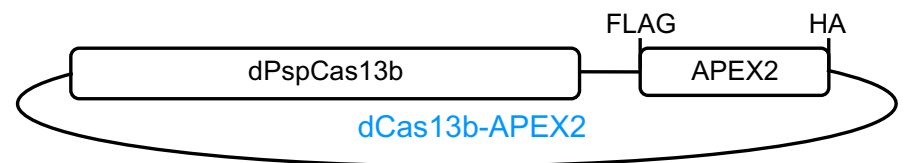

C

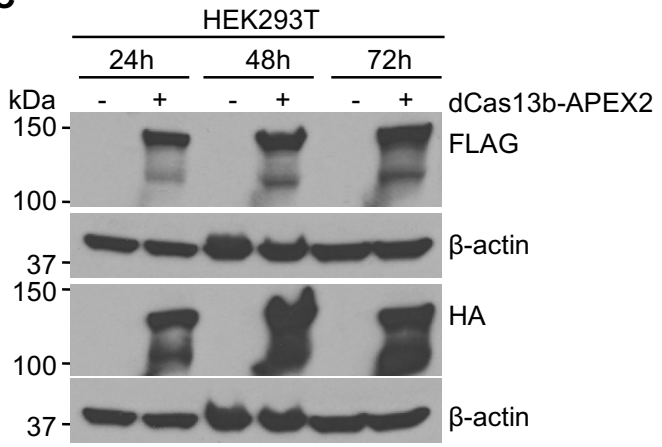

D HEK293T

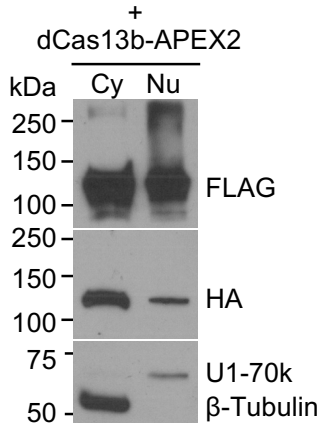

E

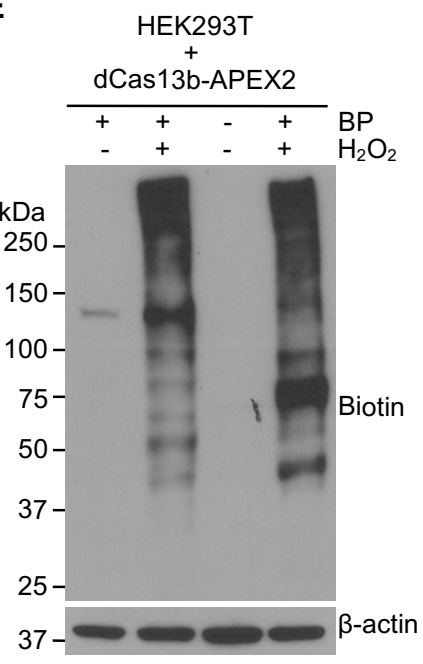

Fig. 1

94 Figure 1. Designing and developing the RPL method. (A). Schematic illustration of RPL workflow. A

95 sequence-specific gRNA directs dCas13-APEX2 to target RNA and APEX2 in the fusion protein biotinylates

96 target RNA proximal proteins (RPPs) in vivo in the presence of biotin-phenol and $\mathrm{H}_{2} \mathrm{O}_{2}$. Biotinylated RPPs

97 are then enriched using streptavidin beads and analyzed by liquid chromatography-tandem mass

98 spectrometry (LC-MS/MS). (B). Diagram of the fusion protein dPspCas13b-FLAG-APEX2-HA (dCas13b-

99 APEX2, or the RPL protein) expression construct. (C). Expression validation of the RPL protein by western blot. HEK293T cells transfected with or without the RPL plasmid were harvested $24 \mathrm{~h}-72 \mathrm{~h}$ post transfection and whole cell lysates were blotted with an anti-FLAG or anti-HA antibody. (D). The RPL protein is expressed in both cytoplasm and nucleus. HEK293T cells transfected with the RPL plasmid for 24h were fractionated into cytoplasmic $(\mathrm{Cy})$ and nuclear $(\mathrm{Nu})$ fractions. Fractionation efficiency was evaluated by blotting cytoplasmic protein $\beta$-Tubulin and nuclear protein U1-70k. (E). Validation of enzymatic activity of APEX2 in the RPL protein. HEK293T cells transfected with the RPL plasmid were treated with different combinations of biotin-phenol (BP) and $\mathrm{H}_{2} \mathrm{O}_{2}$. Whole cell lysates were blotted with anti-biotin antibody. $\beta$ actin in (C) and (E) was used as loading control. 
108 antibody (Figure 1C). The subcellular localization of the RPL protein was examined when

109 ectopically expressed in HEK293T cells. Efficient separation between cytoplasmic and

110 nuclear fractions was confirmed by blotting for cytoplasmic marker $\beta$-Tubulin and nuclear

111 marker U1-70k. The RPL protein was detected in both cytoplasm and nucleus (Figure

112 1D). To test if peroxidase activity of APEX2 is maintained in the RPL protein, HEK293T

113 cells were treated with different combinations of BP and $\mathrm{H}_{2} \mathrm{O}_{2} 24$ h post transfection of the

$114 \mathrm{RPL}$ plasmid. The detection of biotinylated proteins requires both $\mathrm{BP}$ and $\mathrm{H}_{2} \mathrm{O}_{2}$, indicating

115 that APEX2 in the RPL protein retains peroxidase activity (Figure 1E). The results also

116 suggest that endogenous biotinylated proteins are rare in HEK293T cells and low level of

117 endogenous $\mathrm{H}_{2} \mathrm{O}_{2}$ (Belousov et al., 2006; Huang and Sikes, 2014; Lyublinskaya and

118 Antunes, 2019) could not trigger efficient biotinylation. These data suggest that the RPL

119 protein has peroxidase activity and can be applied to target both cytoplasmic and nuclear

120 transcripts.

121

122 Design and validation of gRNAs targeting U1 snRNA

123 To test the approach, we asked whether U1 snRNA proximal proteins (U1 RPPs)

124 identified with the RPL protein include any known U1 RBPs. The U1 snRNA was selected

125 for three reasons: (1) its high abundance (Gesteland, 1993), (2) its structures in human

126 U1 small nuclear ribonucleoprotein (snRNP) and in spliceosome have been solved

127 (Charenton et al., 2019; Pomeranz Krummel et al., 2009; Weber et alı, 2010), and (3)

128 its interacting proteins in U1 snRNP (Stark et al., 2001) and in spliceosome (Zhou et al.,

129 2002) have been well documented. 
Since Cas13b targets single-stranded RNA (Cox et al., 2017; Smargon et al., 2017),

131 three gRNAs (U1-1, U1-2, and U1-3) targeting $U 1$ single-stranded regions were designed

132 based on its structure in pre-B complex (Charenton et al., 2019) (Figure 2A). We first 133 tested if $U 1$ gRNAs direct wild-type PspCas13b to $U 1$ and cleave it by measuring $U 1$ 134 expression in HEK293T cells cotransfected with wild-type PspCas13b plasmid and 135 plasmid expressing U1 gRNA or nontargeting control (NTC) gRNA at a 1:1 molar ratio. 136 The expression of $U 1$ was significantly lower in U1 gRNA-transfected cells compared with 137 NTC gRNA-transfected cells (Figure 2B). The expression of a group of nontargets with 138 a wide range of abundance was not affected (Figure $2 B$ ), except $U 2$, which may be caused by Cas13b collateral activity (Gootenberg et al., 2018) since U1 and U2 are in 140 close contact during spliceosome assembly. The result indicated that U1 gRNAs can 141 specifically direct PspCas13b to U1. We then tested if U1 gRNAs deliver the RPL protein

142 to U1 using RNA immunoprecipitation (RIP) experiment. Since the U6 promoter is slightly 143 stronger than CMV promoter in HEK293T cells (Lebbink et alı, 2011), a 1:2 molar ratio 144 between the RPL plasmid (CMV promoter) and gRNA expressing plasmid (U6 promoter) was used to avoid nonspecific targeting due to excess RPL protein. The RPL protein was 146 efficiently retrieved by anti-HA but not isotype control IgG (Figure 2C). Analysis of RNA 147 extracted from RIP experiment showed that anti-HA pulled down 5 times more RNA than 148 control (Figure 2D), certifying the RPL protein RNA binding activity. Although there is no 149 significant difference in the amount of RNA pulled down by the RPL protein with NTC or 150 U1 gRNAs (Figure 2D), U1 gRNAs significantly enriched U1 for 2-3-fold compared with 151 NTC gRNA (Figure 2E). The fact that much more abundant $18 S$ was not enriched (Figure 152 2E) suggested that $U 1$ gRNAs are able to specifically direct the RPL protein to $U 1$. 
A

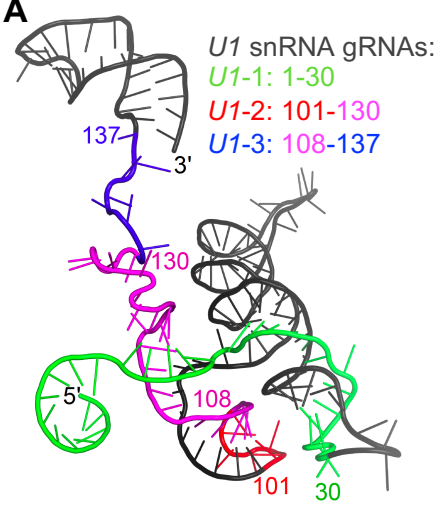

C

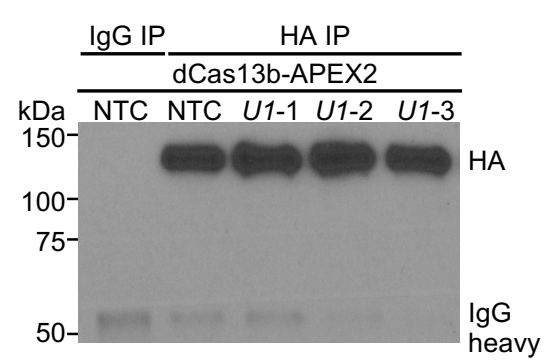

B
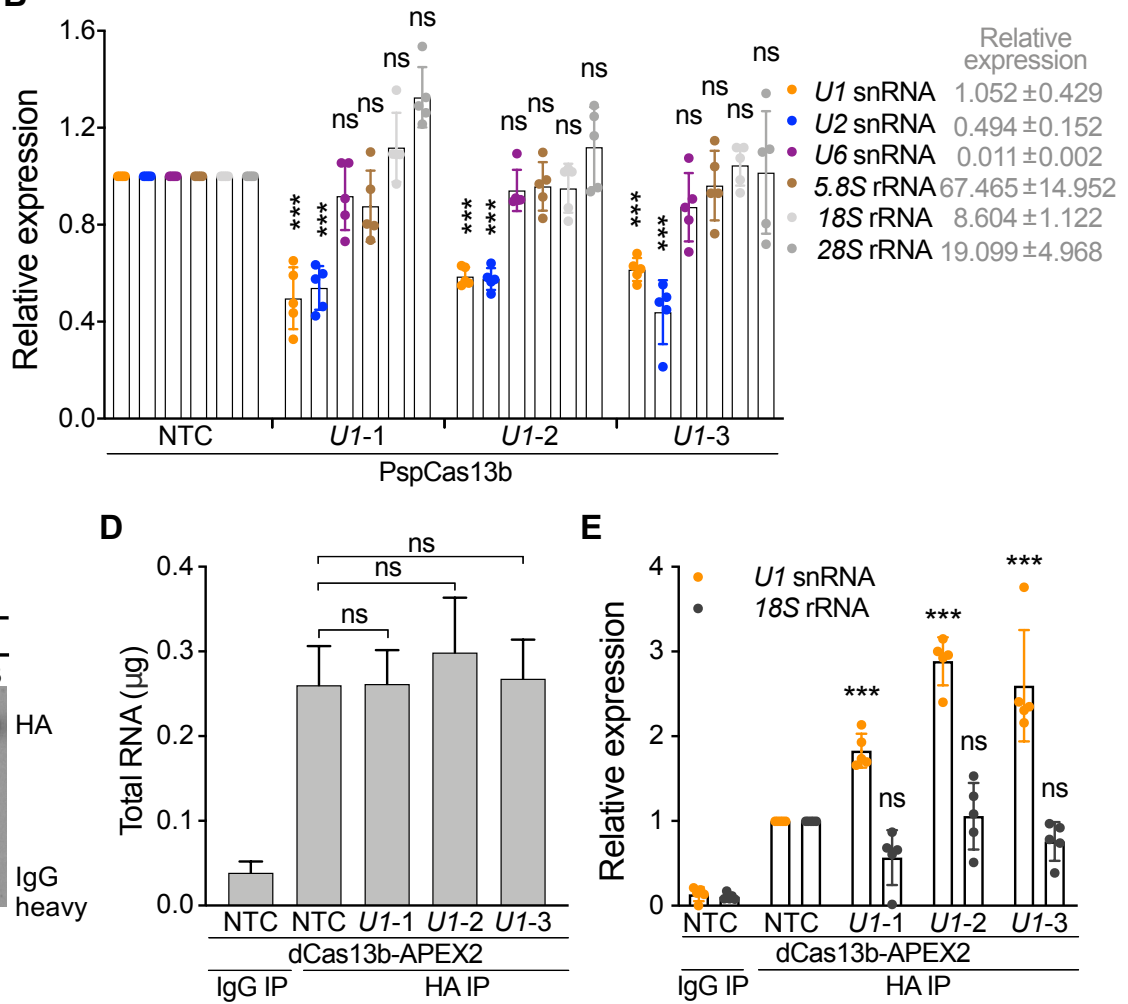

E

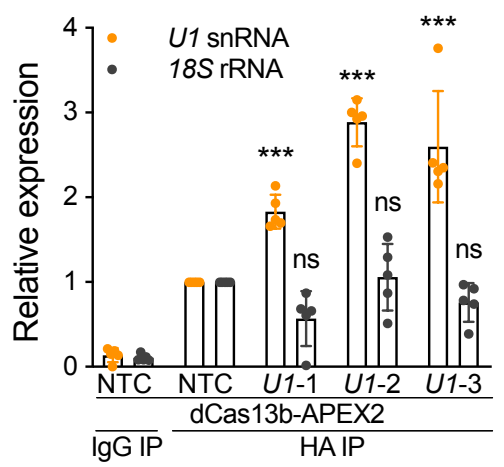

Fig. 2

Figure 2. Designing and validating gRNAs targeting U1 snRNA. (A). Based on U1 structure, three gRNAs with spacers targeting $U 1$ nucleotides (nt) 1-30 (U1-1), 101-130 (U1-2), and 108-137 (U1-3) were designed. Cartoon representation of $U 1$ (PDB ID: 6QX9, pre-B complex) is colored in black, 1-30 in green, 101-107 in red, 108-130 in magenta, and 131-137 in blue. (B). The expression of $U 1$ snRNA was significantly downregulated in U1 gRNA-transfected cells. HEK293T cells were cotransfected with plasmid expressing wild-type PspCas13b and plasmid expressing U1 or NTC gRNA (1:1 molar ratio). The expression of $U 1$ or a group of nontargets was quantified by RT-qPCR and normalized to GAPDH. (C). Confirmation of pulldown of the RPL protein by RIP using western blot. HEK293T cells were cotransfected with the RPL plasmid and plasmid expressing U1 or NTC gRNA (1:2 molar ratio). Anti-HA antibody or isotype control IgG were used to immunoprecipitate the RPL protein. Clean-Blot IP detection reagent was used for blotting. (D). The amount of total RNA extracted from RIP experiment. (E). U1 gRNAs specifically directed the RPL protein

165 to U1. The expression of U1 snRNA and nontarget $18 S$ rRNA was quantified by RT-qPCR and normalized 166 to $G A P D H$. Data shown in (B), (D), and (E) are mean \pm SD from 5 independent experiments. ${ }^{* * *} p<0.001$, ns, not significant. Student's $t$ test. 


\section{RPL-MS identified both $U 1$ canonical and noncanonical roles-related proteins}

169

170

171

172

173

174

175

176

177

178

179

180

181

182

183

184

185

186

187

188

189

190

We next enriched U1 RPPs using RPL with the same 1:2 molar ratio to avoid excess RPL protein that can cause nonspecific targeting and proximity labeling. $U 1$ has compact structure in pre-B complex (Charenton et al., 2019) (Figure 2A) and its size (less than $\sim 10 \mathrm{~nm}$ in diameter) is much smaller than the biotinylating range of APEX2 (likely $\sim 20-40$ nm or larger in diameter) (Fazal et al., 2019; Padrón et al., 2019; Rhee et al., 2013), so we considered experiments using our three $U 1$ gRNAs as replicates. We analyzed streptavidin-enriched biotinylated proteins by LC-MS/MS (RPL-MS). Using label-free intensity-based absolute quantification (iBAQ) values to measure enrichment in U1 gRNA relative to protein amounts in the NTC gRNA sample, RPL-MS identified 226 U1 RPPs ( $p$ $<0.05$ and $\log _{2}$ fold change $[F C]>2$, false discovery rate $[F D R]<0.25$, BenjaminiHochberg method), including known U1 direct RBPs (e.g. SNRNP70, also known as U170k) (Stark et al., 2001) and RBPs that likely interact with U1 indirectly due to their function in the spliceosome (e.g. SNRPA1 and SNRPB2) (Zhou et al., 2002) (Figure 3A, Table S1). We verified the enrichment of U1-70k using western blot and found that it was enriched $\sim 2$-fold by all three U1 gRNAs (Figure 3B), consistent with RPL-MS results (Figure 3A). Analysis of KEGG pathways enriched in the group of U1 RPPs using STRING (Szklarczyk et al., 2019) showed that 'Spliceosome' is the most significantly enriched pathway (FDR $\left.<10^{-8}\right)$ (Figure 3C). Indeed, U1 RPPs included 99 splicing and related factors (Cvitkovic and Jurica, 2013), 56 proteins previously found by U1 ChIRPMS (C. Chu et al., 2015), and 58 proteins revealed by XLIP-MS using anti-U1A and/or anti-U1-70k antibody (So et al., 2019) (Figure 3D). In addition, the binding between U1 and four U1 RPPs was further supported by corresponding CLIP-Seq data as shown in 


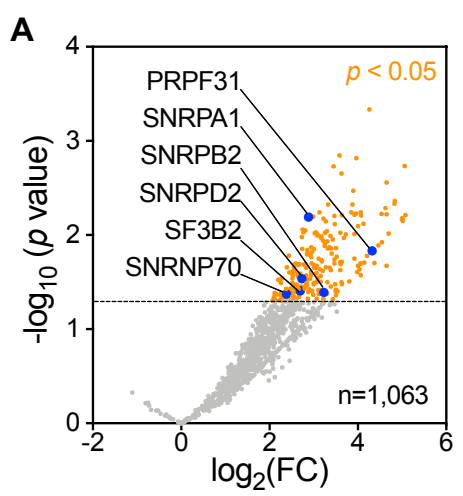

D

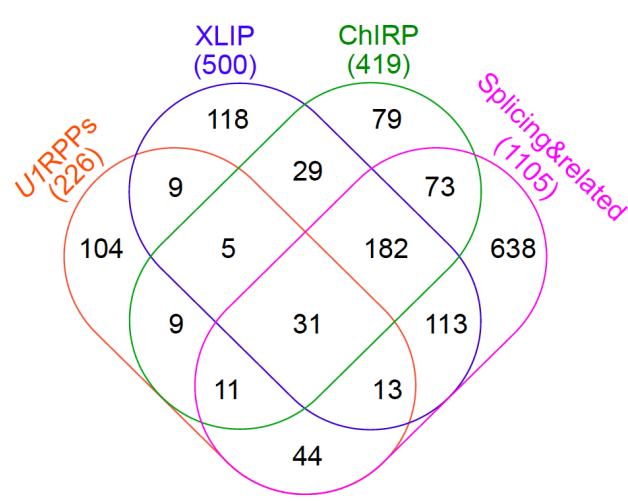

B

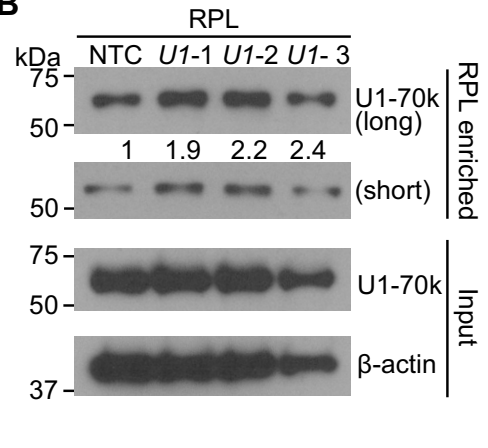

C

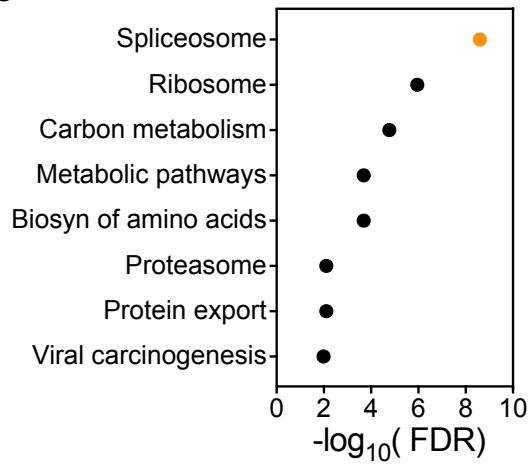

E

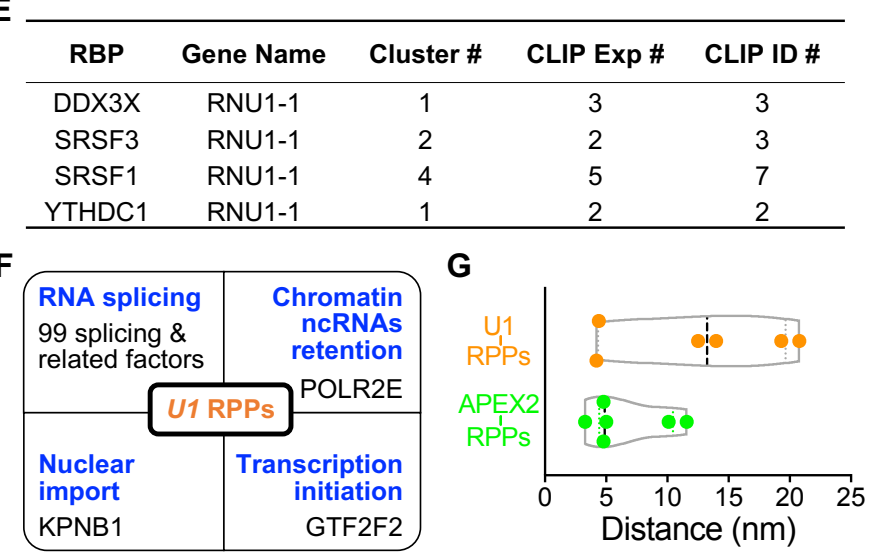

Fig. 3

191

192 Figure 3. U1 RPPs identified by RPL-MS. (A). U1 RPPs revealed by RPL-MS include known U1 RBPs.

193 Volcano plot shows U1/NTC iBAQ ratio (fold change, FC) of protein quantification in U1 gRNA cells compared with NTC gRNA cells. RPL-MS enriched 226 U1 RPPs (orange dots) that were statistically significant $\left(p<0.05\right.$ and $\log _{2} \mathrm{FC}>2, \mathrm{FDR}<0.25$, Benjamini-Hochberg method). Each dot represents the average value from experiments using three U1 gRNAs. Blue dots represent proteins from pre-B spliceosome complex. (B). U1 direct RBP U1-70k was enriched by RPL. HEK293T cells transfected with the RPL plasmid and plasmid expressing U1 gRNA or NTC gRNA were treated with BP and $\mathrm{H}_{2} \mathrm{O}_{2}$. Whole cell lysates (Input) or streptavidin-enriched biotinylated proteins (RPL enriched) were blotted. Numbers represent relative amount of $\mathrm{U} 1-70 \mathrm{k}$ under the corresponding conditions from RPL enriched normalized to input. (C). KEGG pathways significantly enriched by 226 U1 RPPs using STRING. (D). Comparison of U1 RPPs, U1 interactors identified by ChIRP-MS, U1 interactors identified by XLIP-MS using anti-U1A and/or anti-U1-70k antibody, and splicing \& related proteins. Numbers listed below are total number of proteins from each group. (E). List of 4 U1 RPPs with CLIP-Seq data supporting their association of U1 found in 
ENCORI. (F). Summary of U1 RPPs related to $U 1$ functions. (G). Inferred distances between $U 1$ or APEX2 in the RPL protein and those 6 U1 RPPs present in pre-B complex shown in (A).

207

ENCORI ( Li et al., 2014), including DDX3X that is not known to interact with U1 in human (Deckert et al., 2006; Tarn and Chang, 2009) (Figure 3E). These results together validated that RPL can efficiently identify most known RBPs for U1. of $U 1$ in chromatin retention of ncRNAs (Yin et al., 2020). Moreover, U1 RPL retrieved proteins involved in chromatin remodeling, DNA modification, histone modification, and transcription (Table S1), which could be regulated by chromatin-associated ncRNAs (Huang et al., 2020; Li and Fu, 2019). The presence of GTF2F2 among the U1 RPPs may relate to a role for $U 1$ in regulation of transcription initiation (Damgaard et al., 2008;

218 Kwek et al., 2002) (Figure 3F). Interestingly, RPL-MS revealed nuclear import receptor importin- $\beta 1$ (KPNB1) (Figure 3F), which is required for $U 1$ nuclear import (Palacios, 1997). Six RBPs in pre-B complex (Charenton et alı, 2019) were identified as U1 RPPs

221 (Figure 3A). Their distances to U1 snRNA in pre-B complex may provide insight to the 222 biotinylating range of the RPL protein. The inferred distances between APEX2 in the RPL 223 protein and those RBPs are all smaller than $12 \mathrm{~nm}$ and the average is $6.6 \mathrm{~nm}$ (Figure $2243 G)$, suggesting that APEX2 may biotinylate proteins within $12 \mathrm{~nm}$. The inferred distances 225 between $U 1$ and associated RBPs range from $4.2 \mathrm{~nm}$ to $20.8 \mathrm{~nm}$ with an average of 12.5 $226 \mathrm{~nm}$ (Figure 3G), suggesting that RPL can biotinylate proximal proteins within $\sim 20 \mathrm{~nm}$ of 227 target RNA. These data indicated that RPL enables efficient identification of validated 228 RBPs associated with both canonical and noncanonical functions of $U 1$. 


\section{RPL-MS recalled expected categories of proteins for poly(A) tails}

231 To further test the generality of RPL method, we applied it to poly $(A)$ tails, which are adenosines added to the 3' ends of the majority of eukaryotic mRNAs and many IncRNAs in the absence of template (Derrien et al., 2012; Guttman et al., 2009; Tian, 2005," Yang

234 et al., 2011). Poly(A) tails play critical role in mRNA translation and stability (Dreyfus and Régnier, 2002) and their removal triggers mRNA decapping and decay (Muhlrad et al., 1994; Norbury, 2013; Yamashita et al., 2005). Although the 5' and 3' ends of pretranslational mRNAs (Metkar et al., 2018) and deadenylating mRNAs (Chen and Shyu, 2011) are distant (Figure 4A, 5'-3" distance), the physical distances between the two ends of diverse RNAs are incredibly close regardless of their length, type, species, or complexity (Lai et al., 2018; Leija-Martínez et al., 2014) (Figure 4A, 5’-3” proximity).

As oligomers of $30 \mathrm{nt}$ poly(U) are not found at the 3' of RNA (Chang et alı, 2014; Lim et

243 gRNA, was used as negative control. The RPL plasmid was cotransfected with plasmid expressing poly(A) or poly(U) gRNA into HEK293T cells at a 1:2 molar ratio and then RPL was performed. Using label-free iBAQ values to measure enrichment in poly $(A) g R N A$

246 relative to protein amounts in the poly(U) gRNA sample, RPL-MS enriched 786 proteins

247 as poly(A) tail RPPs (Benjamini-Hochberg-adjusted $p<0.05$ and $\log _{2} F C>2$ ) (Figure 4B,

248 Table S2). Poly(A) tail RPPs included seven poly(A) binding proteins, fifteen 3'UTR 249 binding proteins, ten 5'UTR binding proteins, and one cap binding protein (Figure 4B, 250 Table S3), all of which are known to associate with poly(A) tails. Retrieval of proteins from 251 both 5' and 3' ends by RPL within a small radius provided additional evidence for poly $(\mathrm{A})^{+}$ 
RNA 5'-3' proximity.

255 theory, poly(A) gRNA can direct the RPL protein to any transcripts with 30 nt-poly(A) tail

256 or longer (Figure 4A), including transcripts undergoing polyadenylation, readenylation,

257 deadenylation, or translation. We then interrogated poly(A) tail RPPs for other expected 258 classes of proteins, including factors involved in polyadenylation (Shi and Manley, 2015), 259 readenylation or deadenylation (Yan, 2014), and translation (Dreyfus and Régnier, 260 2002). Indeed, RPL-MS enriched five cleavage and polyadenylation factors for poly(A) ${ }^{+}$

261 RNA (Figure 4D) but no such factors unique for poly(A)- RNA (e.g. SLBP and ZNF473) 262 (Gilmartin, 2005) (Table S3). Moreover, poly(A) tail RPPs included three exosome 263 proteins (Chlebowski et al., 2013), two deadenylase complex proteins (Collart, 2016), 264 as well as decapping factor EDC3 (Mugridge et al., 2018) (Figure 4D, Table S3). 265 Importantly, twenty translation initiation factors, fifteen translation elongation factors, 266 seventy ribosomal subunits, and eighteen tRNA ligases were identified by RPL-MS 267 (Figure 4D, Table S3), putatively supporting a model that poly(A) tail recruits translation 268 initiation factors to initiate translation at the 5' end like their viral counterparts (Simon and 269 Miller, 2013; Truniger et al., 2017). Moreover, RPL-MS revealed twelve proteins 270 involved in degradation of AU-rich element-containing mRNAs and 66 nonsense271 mediated decay proteins (including 58 ribosomal subunits) (Chang et al., 2007; Laroia 272 et al., 2002, 1999) (Table S3), further suggesting that RPL enables efficient discovery of 273 most relevant and validated RBPs proximal to poly(A) tails. 
A

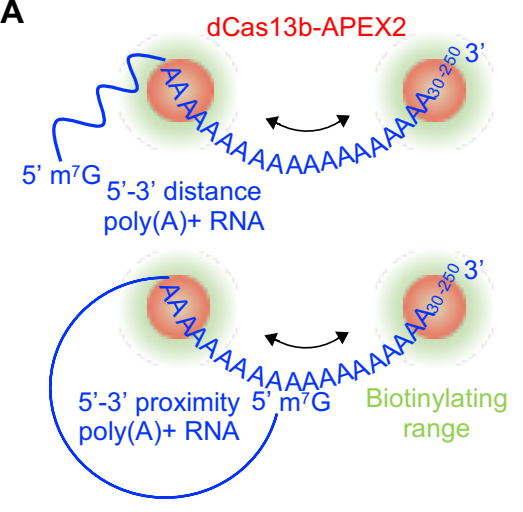

C

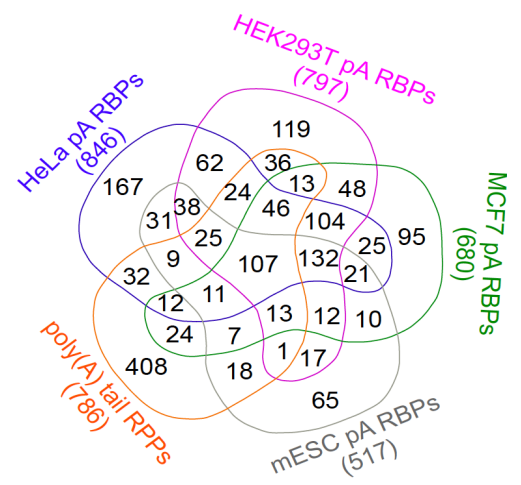

B

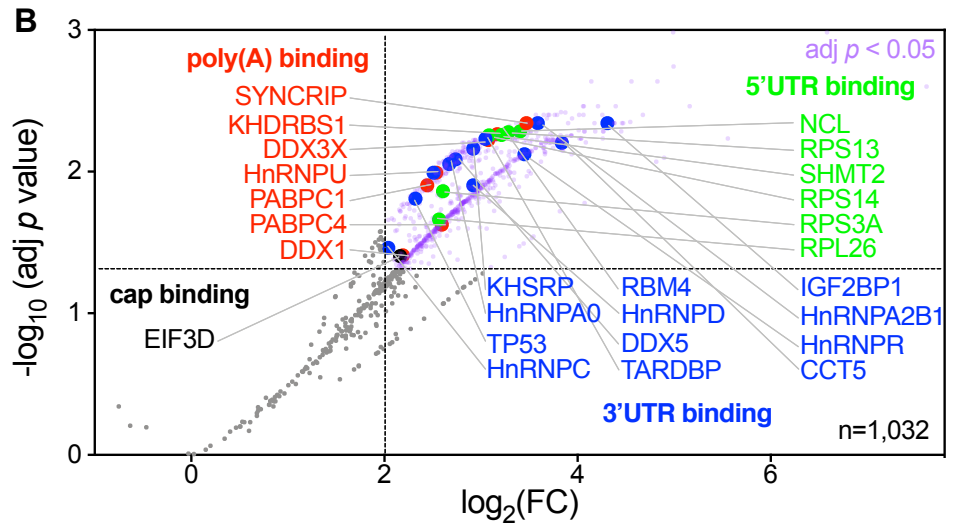

D

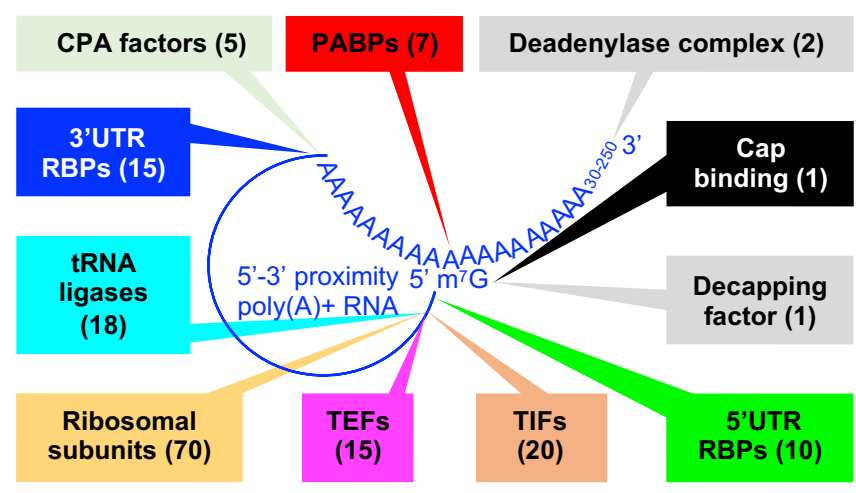

274

275

276

277

278

279

280

281

282

283

284

285

286

287

288

Figure 4. RPL-MS revealed poly(A) tail RPPs in HEK293T cells. (A). Application of RPL to poly(A) tails. In the presence of gRNA, the RPL protein (dCas13b-APEX2) is directed to poly(A) tails ranging from 30 nt up to 250 nt. In 5'-3' distance model, RPL will detect PABPs and 3'UTR binding proteins that bind proximal to poly(A) tail within the biotinylating range. In 5'-3' proximity model, RPL will also identify cap-binding proteins and 5'UTR binding proteins that bind proximal to the cap and lie within the biotinylating range. (B). RPL-MS identified poly(A) tail RPPs. Volcano plot shows RPL-labeled proteins in HEK293T cells. For each protein, the poly $(A) / p o l y(U)$ iBAQ ratio reflects the enrichment of identified protein in poly $(A) g R N A$ cells compared with poly $(\mathrm{U})$ gRNA transfected cells. RPL-MS identified 786 proteins (light purple dots) as significantly enriched (Benjamini-Hochberg-adjusted $p<0.05$ and $\log _{2} \mathrm{FC}>2$ ). Each data point represents the average value from biological triplicates. Red dots represent proteins belonging to PABPs, blue dots for 3'UTR binding proteins, green dots for 5'UTR binding proteins, and black dot for cap binding protein. (C). Venn diagram shows the comparison of poly(A) tail RPPs and RBPs associated with poly(A) ${ }^{+}$RNA in different cells. Numbers below each group represent the sizes of the protein cohort. (D). Summary of expected categories of poly(A) tail RPPs that support 5' -3 ' proximity and the role of poly $(A)$ tail in mRNA 
translation. Each category of proteins points to a location/region of poly $(\mathrm{A})^{+}$RNA where they most likely associate with when identified by RPL. PABPs, poly(A) binding proteins; CPA, cleavage and polyadenylation; TIFs, translation initiation factors; TEFs, translation elongation factors.

Localization analysis of poly(A) tail RPPs unveils expanded subcellular

\section{4 localizations for poly(A) ${ }^{+}$RNA}

295 Poly(A) tails are important for RNA nuclear export (Huang and Carmichael, 1996) via

296 the nuclear pore complex (NPC) (Okamura et al., 2015). This is further supported by the 297 presence of 90 mRNA processing factors, 20 mRNA nuclear export proteins, and 13 NPC 298 proteins in poly $(\mathrm{A})$ tail RPPs (Figure 5A). It is not surprising that tRNAs and pre-miRNAs 299 nuclear export factors were also included (Tab/e S3) since their precursors or primary transcripts are also polyadenylated (Caï, 2004; Kadaba et al., 2006). Poly(A) tail RPPs contained eight tRNA processing factors and five tRNA nuclear export factors (Kruse et al., 2000), as well as three pri-miRNA processing factors and two pre-miRNA export factors (Bohnsack et al., 2004," Lund et al., 2004; Yi et al., 2003) (Table S3), supporting

304 that their processing is coupled with export (Kim, 2005; Köhler and Hurt, 2007). Poly(A) tail RPPs recovered 27 RBPs involved in mRNA transport (including zipcodes binding protein IGF2BP1), 48 microtubule proteins, and 139 plasma membrane proteins that are used by mRNAs to achieve different subcellular localizations (Holt and Bullock, 2009; Mofatteh and Bullock, 2017) (Figure 5A), possibly suggesting a role for the poly(A) tail

309 in RNA subcellular localization.

310 Since unique localizations of RPPs reflect target RNA proximal localizations, we built

311 a putative subcellular localization map for poly $(\mathrm{A})^{+}$RNA by comparing poly $(\mathrm{A})$ tail RPPs 312 with proteins extracted from 22 subcellular compartments (Figure 5B, Tab/e S3). The 
313 results are generally consistent with previous reports that both mRNAs and ncRNAs have 314 multiple subcellular localizations (Blower, 2013; Carlevaro-Fita and Johnson, 2019;

315 Fazal et al., 2019; Wilk et al., 2016) and also support the presence of mRNAs in P316 bodies, stress granule, and the exosome (Chlebowski et al., 2013; Decker and Parker,

317 2012). Interestingly, RPL-MS also identified marker proteins of the endosome, lysosome, 318 proteasome, and Golgi apparatus, indicative of expanded subcellular localizations for 319 poly $(A)^{+}$RNA (Figure 5B, Table S3). Discovery of lysosomal and proteasomal proteins 320 in poly(A) tail RPPs is compatible with the existence of RNA degradation pathway 321 'RNautophagy' in the lysosome (Fujiwara et al., 2013) and degradation function of 322 proteasomes for AU-rich element-containing mRNAs (Laroia et al., 2002, 1999). The 323 identification of endosomal proteins is in accordance with that late endosomes can be 324 used by mRNAs as a platform for translation (Cioni et al., 2019). Poly(A) tail RPPs 325 included Golgi marker cis-Golgi matrix protein GOLGA2 (Munro, 2011) (Tab/e S3), which 326 has recently been annotated as an RBP by multiple groups (Caudron-Herger et al., 2019;

327 Queiroz et alı, 2019; Trendel et al., 2019), suggesting that Golgi may be a novel 328 subcellular location for poly $(\mathrm{A})^{+}$RNA. More experimental data are needed to determine 329 which specific transcripts are associated with GOLGA2 in the Golgi apparatus and the 330 biological significance of those interactions. 


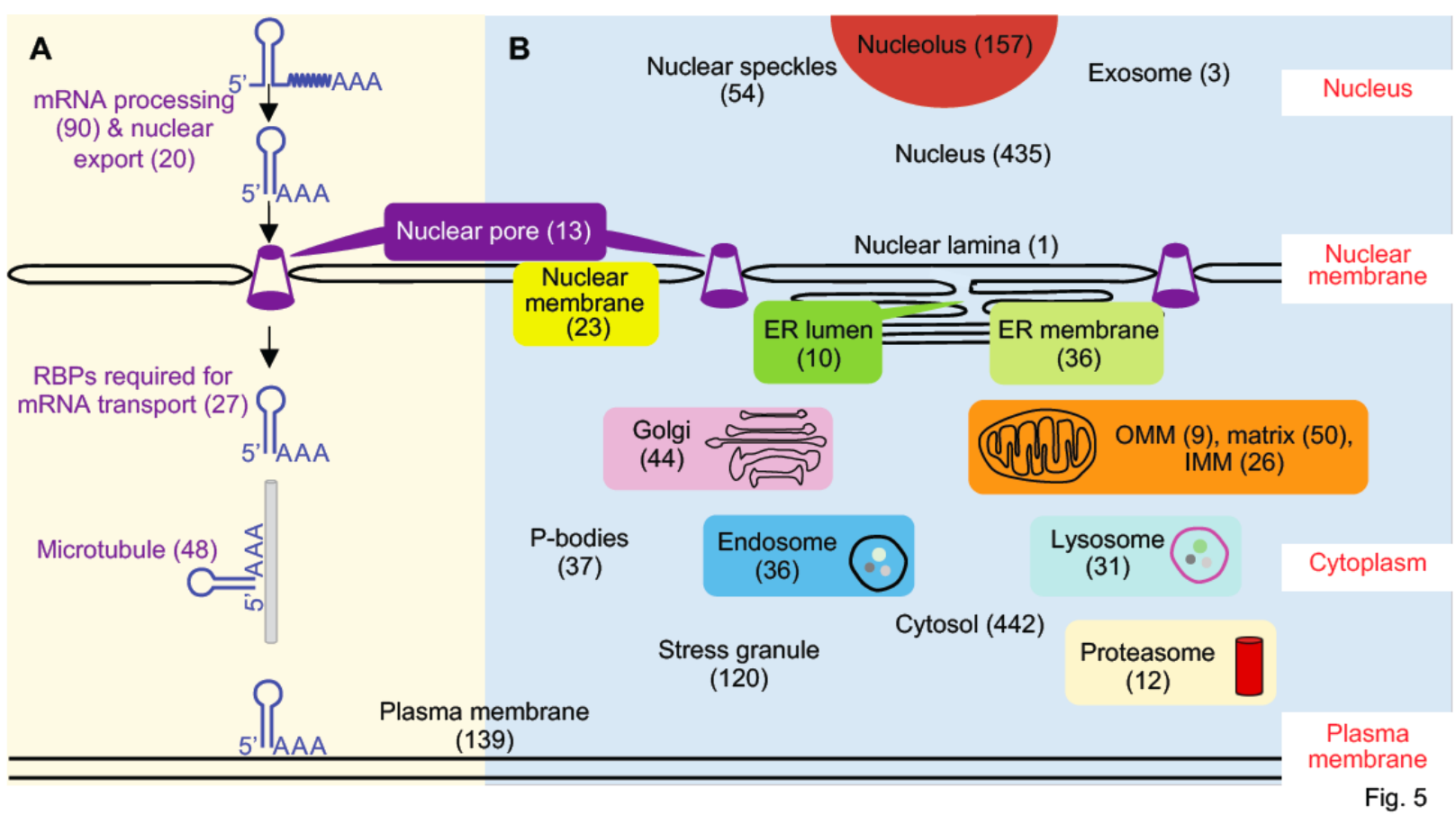

Figure 5. $\operatorname{Poly}(\mathrm{A})$ tail RPPs included proteins involved in subcellular localization of RNA. (A). RPL-MS revealed proteins involved in RNA processing, nuclear export, transport, and subcellular localization for poly(A) tail RPPs. (B). A putative subcellular localization map of poly(A) ${ }^{+}$RNA built upon subcellular localization of poly(A) tail RPPs. Poly(A) tail RPPs were compared with proteins extracted from corresponding GO terms. Numbers in brackets represent the size of each category of proteins. A full list of proteins in each category can be found in Table S3.

\section{Discussion}

RPL: an RNA-centric approach for RPPs identification in living cells

342 We present an RNA-centric method, RPL, for discovering RPPs for transcripts of interest and evaluate it in two distinct contexts-first interrogating a specific ncRNA target $U 1$ and second surveying a heterogenous group of poly $(A)^{+}$RNA in living cells. Both U1 RPPs and poly(A) tail RPPs demonstrated that RPL enables efficient discovery of functional relevant RBPs for target transcripts. The recall of KPNB1 for U1 nuclear import suggests

347 that RPL allows to detect transient and/or weak interacting proteins (Branon et al., 2017; 
348 Roux et al., 2013). Compared with alternative methods, RPL needs no crosslinking or sonication, requires far fewer cells ( 20-40 million vs $\sim 100-800$ million) and involves no genetic manipulation, which may interfere target RNA functions (Laprade et al., 2020).

351 The short pulse of labeling potentially permits RPL to be applied to study RNA-protein

352 dynamics. Recently, APEX2 has also been reported to biotinylate proximal nucleic acids

353 (Fazal et al., 2019; Padrón et al., 2019;" Y. Zhou et al., 2019), suggesting that RPL could

354 be potentially applied to identify RNA and DNA in addition to proteins proximal to the

355 target RNA (together as 'RNA proximitome') within living cells.

During the preparation of our manuscript, similar strategies using different fusion

357 proteins of endonuclease-deficient Cas13 protein (dLwaCas13a, dPspCas13b, and $358 \mathrm{dRfxCas13d}$ ) and proximity labeling enzyme (APEX2, BiolD2, BASU, and PafA) were reported (Han et al., 2020; Li et al., 2020; Yi et al., 2020; Zhang et al., 2020).

360 Applications of these methods together with ours to both mRNAs and ncRNAs with wide 361 range of abundance $\left(\sim 10^{2}-10^{6}\right.$ copies/cell) demonstrate that these methods have broad 362 potential to identify functional relevant RBPs for diverse transcripts.

363 RPPs identified using the dCas13b-APEX2 are expected to include three types of 364 proteins theoretically: proteins that directly bind to target RNA, proteins that associated 365 with target RNA indirectly via protein-protein interactions, and proteins present within the 366 biotinylating range. Biological replicates are expected to help enrich the first two groups 367 of RBPs and reduce the third type as false positive candidates may not be enriched 368 repeatedly. In addition, an optimal molar ratio between the fusion protein and gRNA, 369 which enables efficient proximity-based biotinylation and prevents nonspecific labeling 370 due to excess fusion protein, is crucial for separating signal from noise. A validated set of 
371 gRNAs that can specifically direct fusion protein to target RNA with low off-target activity

372 is another key factor. As complementarity between the gRNA spacer and targeted region

373 as well as local RNA accessibility are essential for RNA targeting (Abudayyeh et al.,

374 2017; Cox et al., 2017; Konermann et al., 2018; Smargon et al., 2017), general

375 principles for gRNA designing can provide critical help in choosing spacer sequence and

376 length for gRNA aiming at single-stranded region of target RNA (Bandaru et al., 2020;

377 Wessels et al., 2020).

\section{Limitations and directions for improvement}

380 High concentration of $\mathrm{H}_{2} \mathrm{O}_{2}(1 \mathrm{mM})$ used in the RPL method may cause oxidative stress 381 and necrosis to the cells (Clément and Pervaiz, 2001) and may preclude the application

382 of RPL to systems sensitive to oxidative stress and cell harm. Similar to other fusion 383 proteins, the RPL protein due to its large size $(\sim 130 \mathrm{kDa})$ may pose steric hindrance to 384 access target RNA and increase the biotinylating range, which could reduce specificity 385 and limit the application to mapping RNA functional domains (Quinn et al., 2014) and 386 RNA-protein interactions at high resolution. Improvement could be achieved using smaller 387 Cas13 proteins by structure-guided truncations (Zhang et al., 2018). Alternatively, CIRTS 388 strategy could be applied to assemble a much smaller gRNA-dependent RNA proximity 389 labeling enzyme (Rauch et al., 2019).

390 Another limitation is that RPL and similar tools may not identify RBPs for a target RNA 391 as efficiently as antisense probe-based methods, as the RPL protein has to compete with 392 the RBPs bound to the target transcript (Wessels et al., 2020). The RPL protein can only 393 access single-stranded regions of target RNA (Cox et al., 2017; Smargon et al., 2017) 
394 and only proteins with electron-rich amino acids like tyrosine exposed on the surface

395 within the biotinylating range have the opportunity to be labeled (Rhee et al., 2013). The

396 same limitation also applies to other proximity labeling enzymes including BiolD and its

397 relatives and PafA, which all favor lysine as labeling substrate (Liu et al., 2018;

398 Samavarchi-Tehrani et al., 2020).

399

400

Perspectives

401 We anticipate that RPL and similar methods will be widely applied to characterize the

402 functions and regulation of diverse categories of RNA in multiple cell types and organisms.

403 Since both Cas13s and proximity labeling are very active research areas, further

404 optimization and refinements of RPL and similar methods are expected. Utilizations of

405 these tools together with protein-centric methods (Licatalosi et al., 2008; Van Nostrand

406 et al., 2016), annotation of RNA structure (Spitale et al., 2015; Sun et al., 2019) could

407 shed light on the molecular mechanisms of IncRNA functions, RNA-protein interactions,

408 RNA functional domain, and binding specificities for RBPs.

409

410 Acknowledgements

411 This work was supported by the Ovarian Cancer Research Alliance (Ann and Sol

412 Schreiber Mentored Investigator Award 458799 to X.L.) and the National Cancer Institute

413 (K99/R00-CA184415 and R01-CA207456 to K.L.), the Cedars-Sinai Samuel Oschin

414 Comprehensive Cancer Institute (Cancer Biology Grant 231433 to K.L.). We thank Drs.

415 Wei Yang and Bo Zhou at the Cedars-Sinai Medical Center Biomarker Discovery Platform 
416 Core for label-free quantitative mass spectrometry analysis. We also thank anonymous

417 reviewers for their insightful comments and suggestions.

\section{Author contributions}

420 X.L conceived the project, designed and performed all experiments, and analyzed the

421 data. R.I.C. and M.A.S.F. analyzed the data. K.L. supervised the project. X.L. and K.L.

422 wrote the manuscript with input from all authors.

423

\section{Competing interests}

425 The authors declare no competing interests. 


\section{Materials and methods}

427 Key Resources Table

\begin{tabular}{|c|c|c|}
\hline Reagent or Resource & Source & Identifier \\
\hline \multicolumn{3}{|l|}{ Antibodies } \\
\hline U1-70k & EMD Millipore & Cat.\# 05-1588, RRID: AB_11210916 \\
\hline$\beta$-tubulin & Sigma Aldrich & Cat.\# T8328, RRID: AB_1844090 \\
\hline $\mathrm{HA}$ & Santa Cruz & Cat.\# sc-7392, RRID: A $\bar{B} \_627809$ \\
\hline FLAG & Santa Cruz & Cat.\# sc-166384, RRID: AB 2017592 \\
\hline Biotin & Santa Cruz & Cat.\# sc-57636, RRID: AB_628778 \\
\hline$\beta$-actin & Santa Cruz & Cat.\# sc-47778, RRID: AB_626632 \\
\hline $\lg G$ & Thermo Fisher Scientific & Cat.\# 10500C, RRID: AB 2532981 \\
\hline \multicolumn{3}{|l|}{ Chemicals } \\
\hline biotin-phenol & Iris Biotech & Cat.\# LS-3500.1000, RRID: N/A \\
\hline hydrogen peroxide $\left(\mathrm{H}_{2} \mathrm{O}_{2}\right)$ & Sigma Aldrich & Cat.\# H1009, RRID: N/A \\
\hline sodium azide & Sigma Aldrich & Cat.\# S2002-5G, RRID: N/A \\
\hline sodium ascorbate & Sigma Aldrich & Cat.\# PHR1279-1G, RRID: N/A \\
\hline Trolox & Sigma Aldrich & Cat.\# 238813-1G, RRID: N/A \\
\hline Dynabeads Protein A & Thermo Fisher Scientific & Cat.\#: 10001D, RRID: N/A \\
\hline Streptavidin magnetic beads & Thermo Fisher Scientific & Cat.\# 88817, RRID: N/A \\
\hline \multicolumn{3}{|l|}{ Plasmids } \\
\hline $\begin{array}{c}\text { pC0046-EF1a-PspCas13b- } \\
\text { NES-HIV }\end{array}$ & Addgene & RRID: Addgene_103862 \\
\hline pC0053-CMV-dPspCas13b- & & \\
\hline $\begin{array}{c}\text { GS-ADAR2DD (E488Q)-delta- } \\
984-1090\end{array}$ & Addgene & RRID: Addgene_103869 \\
\hline $\begin{array}{c}\text { pCMV-dPspCas13b-FLAG- } \\
\text { APEX2-HA }\end{array}$ & This study & N/A \\
\hline pcDNA3-APEX2-NES & Addgene & RRID: Addgene_49386 \\
\hline PspCas13b NTC gRNA & Addgene & RRID: Addgene 103854 \\
\hline PspCas13b U1-1 gRNA & This study & N/A \\
\hline PspCas13b U1-2 gRNA & This study & N/A \\
\hline PspCas13b U1-3 gRNA & This study & N/A \\
\hline PspCas13b poly(A) gRNA & This study & N/A \\
\hline PspCas 13b poly(U) gRNA & This study & $N / A$ \\
\hline \multicolumn{3}{|l|}{ Experimental Models: Cell lines } \\
\hline Human HEK293T cells & ATCC & Cat.\# CRL-3216, RRID: CVCL_0063 \\
\hline \multicolumn{3}{|l|}{ Software and Algorithms } \\
\hline PyMOL & PyMOL & RRID: SCR_000305 \\
\hline Metascape & Metascape & RRID: SCR_016620 \\
\hline STRING & STRING & RRID: SCR_005223 \\
\hline Limma & Limma & RRID: SCR_010943 \\
\hline
\end{tabular}

429 Plasmids and cloning. pC0046-EF1a-PspCas13b-NES-HIV was a gift from Dr. Feng Zhang (Addgene 430 plasmid \# 103862). pCMV-dPspCas13b-FLAG-APEX2-HA (RPL plasmid) was constructed by replacing 431 ADAR2DD-delta-984-1090 in pC0053-CMV-dPspCas13b-GS-ADAR2DD (E488Q)-delta-984-1090 (a gift 432 from Dr. Feng Zhang, Addgene plasmid \# 103869) with FLAG-APEX2-HA subcloned from pcDNA3- 
APEX2-NES (a gift from Dr. Alice Ting, Addgene plasmid \# 49386) using the following primers: dPspCas13b-For: 5'TACCCATACGATGTTCCAGATTACGCTTAAGCGGCCGCTCGAGTC3', dPspCas13b-Rev: 5'GTCGTCATCCTTGTAGTCGGATCCCAGTGTCAGTCTTTCAAG3',

FLAG-APEX2-HA-Rev: 5'TGGAACATCGTATGGGTACTGCAGGGCATCAGCAAAC3'.

438 PCR was performed using Q5 High-Fidelity DNA Polymerase (New England Biolabs, Cat.\# M0491L). PCR

439 fragments were assembled using NEBuilder HiFi DNA Assembly Master Mix (New England Biolabs, Cat.\# E2621S) according to manufacturer's instructions. The following spacer sequences were used to express gRNAs using pC0043-PspCas13b crRNA backbone (a gift from Dr. Feng Zhang, Addgene plasmid \# 442 103854):

443 NTC: ATGTCTTCCTGGGACGAAGACAA

444 U1-11-30: ATCATGGTATCTCCCCTGCCAGGTAAGTAT,

445 U1-2101-130: CAAATTATGCAGTCGAGTTTCCCACATTTG,

U1-3108-137: ACTACCACAAATTATGCAGTCGAGTTTCCC,

Poly(A): TTTTTTTTTTTTTTTTTTTTTTTTTTTTTT,

448 Poly(U) : AAAAAAAAAAAAAAAAAAAAAAAAAAAAAA.

449 The sequences of all constructs have been confirmed using Sanger sequencing.

451 Transfection and in vivo proximity dependent biotinylation. For validation of U1 gRNAs in directing the 452 RPL protein to target U1, HEK293T cells were seeded into 12-well plates and were transfected with $1.5 \mu \mathrm{g}$ 453 the RPL plasmid and $0.5 \mu \mathrm{g}$ Cas13b gRNAs (NTC, U1-1, U1-2, U1-3) while $\sim 80 \%$ confluency using 454 Lipofectamine 3000 (Thermo Fisher Scientific, Cat.\# L3000015). For RIP experiments, HEK293T cells were 455 seeded into 6-well plates and were transfected with $2.5 \mu \mathrm{g}$ the RPL plasmid and $1.5 \mu \mathrm{g}$ Cas13b gRNAs 456 while $\sim 80 \%$ confluency using Lipofectamine 3000 . For proximity-dependent biotinylation, HEK293T cells 457 were seeded into $150 \mathrm{~mm}$ plate and were transfected with $25 \mu \mathrm{g}$ the RPL plasmid and $15 \mu \mathrm{g}$ Cas $13 \mathrm{~b}$ gRNAs 458 (NTC, U1-1, U1-2, U1-3, poly[A], poly[U]) while $~ 80 \%$ confluency using Lipofectamine 3000. HEK293T cells 459 were incubated with $25 \mathrm{~mL}$ of DMEM media containing $25 \mu \mathrm{L}$ of $500 \mathrm{mM}$ biotin-phenol (Iris Biotech, Cat.\# 460 LS-3500.1000) in DMSO for $30 \mathrm{~min}$ at $37^{\circ} \mathrm{C} 24 \mathrm{~h}$ post transfection. Cells were then treated with $1 \mathrm{mM}$ 
461 hydrogen peroxide $\left(\mathrm{H}_{2} \mathrm{O}_{2}\right)$ (Sigma Aldrich, Cat.\# $\left.\mathrm{H} 1009\right)$ for $1 \mathrm{~min}$ on a horizontal shaker at room

462 temperature. The labeling solution was aspirated and cells were washed twice with $25 \mathrm{~mL}$ of quencher

463 solution (10 mM sodium azide [Sigma Aldrich, Cat.\# S2002-5G], 10 mM sodium ascorbate [Sigma Aldrich,

464 Cat.\# PHR1279-1G], and 5 mM Trolox [Sigma Aldrich, Cat.\# 238813-1G] in DPBS (Thermo Fisher Scientific,

465 Cat.\# 14040182). Cells were then washed three times with $15 \mathrm{~mL}$ of DPBS and were pelleted by

466 centrifugation at $1,500 \mathrm{~g}$ for $5 \mathrm{~min}$ at $4{ }^{\circ} \mathrm{C}$. Cell pellets were snap frozen and stored at $-80^{\circ} \mathrm{C}$.

Streptavidin enrichment of biotinylated proteins. Cell pellets from two $150 \mathrm{~mm}$ plates of transfected HEK293T cells were lysed in $2 \mathrm{~mL}$ cell lysis buffer (10 mM HEPES, pH7.5 by KOH, $150 \mathrm{mM} \mathrm{NaCl,} 0.1 \%$ NP-40, 5 mM EGTA, 5 mM Trolox, 10 mM Sodium ascorbate acid, 10 mM Sodium azide, 1 mM PMSF).

471 Streptavidin magnetic beads (Thermo Fisher Scientific, Cat.\# 88817) were washed twice with cell lysis

472 buffer and $3.5 \mathrm{mg}$ of each whole cell lysate sample were incubated with $100 \mu \mathrm{L}$ magnetic bead slurry with

473 rotation for $2 \mathrm{~h}$ at room temperature. After enrichment, the flowthrough was removed and beads were 474 washed with $2 \times 1 \mathrm{~mL}$ cell lysis buffer, $1 \mathrm{~mL} 1 \mathrm{M} \mathrm{KCl}, 1 \mathrm{~mL} 0.1 \mathrm{M} \mathrm{Na}_{2} \mathrm{CO}_{3}, 1 \mathrm{~mL}$ of $2 \mathrm{M}$ urea in $10 \mathrm{mM}$ Tris$475 \mathrm{HCl}(\mathrm{pH} 8.0)$, and again with $2 \times 1 \mathrm{~mL}$ cell lysis buffer. Biotinylated proteins were then eluted by boiling the 476 magnetic beads in $30 \mu \mathrm{L} 4 \times$ Laemmli sample buffer (Bio-Rad, Cat.\# 1610747) supplemented with $20 \mathrm{mM}$ 477 DTT and $2 \mathrm{mM}$ biotin.

\section{LC-MS/MS and label-free quantitative mass spectrometry proteomic analysis}

480 The streptavidin-enriched proteins were profiled using label-free quantitative mass spectrometry as 481 previously described (B. Zhou et al., 2019) at Cedars-Sinai Medical Center Biomarker Discovery Platform 482 Core.

\section{Data analysis for RNA proximal proteins}

485 Data were first filtered to exclude non-human proteins and proteins that were detected in only one or none 486 of the $U 1$ replicates or poly $(A)$ replicates. Then proteins detected with two or greater unique peptides were 487 subjected to $\log _{2}$ transformation. Only the top gene name was kept from multiple candidates. Since $U 1$ has 488 compact structure in pre-B complex and its size is much smaller than the biotinylating range of APEX2, 
experiments using U1 gRNAs (U1-1, U1-2, U1-3) were considered as replicates to compare with nontargeting controls (NTC1, partially [65\%] targeting UBTF; NTC2, targeting poly[A]; NTC3, targeting

491 poly[U]). Moderated $t$-test with a paired design was used to compare the $\log _{2}$-transformed iBAQ values 492 between $U 1$ and NTC or between poly(A) and poly(U) using limma package (Smyth, 2004). $p$ values were 493 adjust using the Benjamini-Hochberg (BH) method (Benjamini and Hochberg, 1995) for multiple 494 comparisons. Proteins with $p<0.05$ were considered statistically significant. There are 226 U1 RPPs with $495 p<0.05, \log _{2} \mathrm{FC}>2$, FDR $<0.25$ and 786 poly(A) tail RPPs with $\mathrm{BH}$-adjusted $p<0.05, \log _{2} \mathrm{FC}>2$.

\section{Comparison RPPs with different gene ontology (GO) terms}

498 Lists of human proteins were retrieved (04/13/2020) from QuickGO (https://www.ebi.ac.uk/QuickGO/) via searching corresponding GO terms and selecting 'Homo sapiens (9606)' under Taxon, except P-bodies and stress granule, which were both curated using data summarized from Wikipedia (04/24/2020) were generated using online tools (http://bioinformatics.psb.ugent.be/webtools/Venn/).

Cellular fractionation. Cells were fractionated as previously described with slight modification (Lin et al., 2019). Six million HEK293T cells were treated with PML buffer (10 mM Tris-HCl, pH 7.5, 0.15\% NP-40, 150 $\mathrm{mM} \mathrm{NaCl}$ ) on ice for $4 \mathrm{~min}$ after homogenization by flicking. Lysates were loaded onto a $24 \%$ sucrose cushion (24\% RNase-free sucrose in PML buffer) using large orifice tips, and centrifuged at 15,000 $\times g$ for $10 \mathrm{~min}$ at $4^{\circ} \mathrm{C}$. The supernatant (cytoplasmic fraction) was retained and the pellet (nuclear fraction) was washed with $1 \times \mathrm{PBS} / 1 \mathrm{mM}$ EDTA and resuspended in $200 \mu \mathrm{L}$ of $1 \times \mathrm{PBS} / 1 \mathrm{mM}$ EDTA. Fractionation

510 efficiency was validated by western blot using $\beta$-tubulin (Sigma Aldrich, Cat.\# T8328, 1:2,000) as 511 cytoplasmic marker and U1-70k (EMD Millipore, Cat.\# 05-1588, 1:1,000) as nuclear marker.

513 RNA Immunoprecipitation (RIP). RIP was performed as previously described with slight modification (Lin 514 et al., 2019). Twelve microliter Dynabeads Protein A (Thermo Fisher Scientific, Cat.\#: 10001D) were 515 washed with $200 \mu \mathrm{L} \mathrm{HBS}(150 \mathrm{mM} \mathrm{NaCl}, 10 \mathrm{mM} \mathrm{HEPES}, \mathrm{pH} 7.5$ by $\mathrm{KOH}$ ) and incubated with $2 \mu \mathrm{g}$ anti-HA 516 (Santa Cruz, Cat.\# sc-7392) or $2 \mu \mathrm{g}$ rabbit IgG isotype (Thermo Fisher Scientific, Cat.\# 10500C) in the 
517 presence of $80 \mu \mathrm{L} \mathrm{HBS}$ buffer at room temperature for $1 \mathrm{~h}$. Eight million HEK293T cells were lysed with $518800 \mu \mathrm{L}$ cell lysis buffer (HBS, 0.1\% NP-40, 5 mM EGTA, supplemented with $1 \times$ protease inhibitor cocktail

519 [Roche, Cat.\# 11873580001], 1 × PhosSTOP protease inhibitor cocktail [Roche, Cat.\# 4906837001], 1 mM

520 PMSF [Sigma Aldrich, Cat.\# 93482], and Superase-in [Ambion, Cat.\# AM2696]) at $4^{\circ} \mathrm{C}$ for $1 \mathrm{~h}$. Cell debris

521 and insoluble proteins were removed by centrifugation at $4^{\circ} \mathrm{C}, 12,000 \mathrm{~g}$ for $10 \mathrm{~min}$, and the supernatants

522 were incubated with HA-conjugated or IgG-conjugated Dynabeads at $4^{\circ} \mathrm{C}$ for $1 \mathrm{~h}$. The Dynabeads were

523 then washed 3 times with wash buffer (HBS, 0.1\% NP-40) and aliquoted into two halves. Proteins

524 associated with half of the Dynabeads were eluted with $22 \mu \mathrm{L} 4 \times$ Laemmli sample buffer (Bio-Rad, Cat.\#

5251610747 ) by boiling at $95^{\circ} \mathrm{C}$ for 5 min. RNA was extracted from the other half of Dynabeads using TRIzol

526 LS (Thermo Fisher Scientific, Cat.\# 10296028).

527

528 RNA extraction and RT-qPCR. RNA associated with immunoprecipitated RPL fusion protein or RNA from 529 gRNA transfected cells were extracted using TRIzol LS. M-MLV reverse transcriptase (Promega, Cat.\# 530 M5301) and random hexamers (Promega, Cat.\# C1181) were used for reverse transcription. Gene 531 expression was quantified by RT-qPCR using iQ SYBR Green supermix (Bio-Rad, Cat.\# 170-8886). The 532 relative gene expression was calculated using the $2^{-\Delta \Delta C t}$ method and normalized to GAPDH. Five 533 nanograms cDNA was used for RT-qPCR analysis on CFX96 Touch Real-Time PCR Detection System 534 (Bio-Rad) using the following primer pairs:

535 U1-RT-For: 5'CCAGGGCGAGGCTTATCCATT3', U1-RT-Rev: 5'GCAGTCCCCCACTACCACAAAT3';

536 U2-RT-For: TTCTCGGCCTTTTGGCTAAG; U2-RT-Rev: CTCCCTGCTCCAAAAATCCA;

537 U6-RT-For: GCTTCGGCAGCACATATACTAAAAT; U6-RT-Rev: CGCTTCACGAATTTGCGTGTCAT;

538 5.8S-RT-For: GGTGGATCACTCGGCTCGT; 5.8S-RT-Rev: GCAAGTGCGTTCGAAGTGTC;

539 18S-RT-For: 5'CAGCCACCCGAGATTGAGCA3', 18S-RT-Rev: 5'TAGTAGCGACGGGCGTGTG3';

540 28S-RT-For: CCCAGTGCTCTGAATGTCAA; 28S-RT-Rev: AGTGGGAATCTCGTTCATCC;

541 GAPDH-RT-For: 5'TGCCAAATATGATGACATCAAGAA3',

542 GAPDH-RT-Rev: 5'GGAGTGGGTGTCGCTGTTG3'. 
544 Western blot. Protein samples were run on 4-20\% gradient precast protein gel (Bio-Rad, Cat.\# 456-1096)

545 and transferred onto PVDF membrane (Bio-Rad, Cat.\# 1704157). After $1 \mathrm{~h}$ blocking, membranes were

546 incubated with anti-FLAG (Santa Cruz, Cat.\# sc-166384, 1:1,000), anti-HA (Santa Cruz, Cat.\# sc-7392,

547 1:1,000), anti-biotin (Santa Cruz, Cat.\# sc-57636, 1:1,000), or anti- $\beta$-actin (Santa Cruz, Cat.\# sc-47778,

$548 \quad 1: 2,000)$ at $4^{\circ} \mathrm{C}$ overnight. Membranes were washed three times with Tris-buffered saline containing $0.5 \%$

549 Tween 20 (TBST) before incubating with HRP-conjugated secondary antibody at room temperature for $2 \mathrm{~h}$.

550 Then the membranes were incubated briefly with ECL Western Blotting Substrate (Thermo Fisher Scientific,

551 Cat.\#: 32106) after three times wash with TBST. The membranes were exposed to HyBlot Autoradiography

552 Film (Denville Scientific, Cat.\#: E3018).

553

554 Distance calculation. The distances between U1 snRNA and U1 RPPs identified by RPL in the pre-B

555 complex structure (PDB ID: 6QX9) were measured using PyMOL (Schrodinger, 2020). We used the

556 distance from U1 snRNA (nucleotide 1) to the proximal residues of U1 RPPs to estimate the actual distance

557 (D1). Since there is no structure available for PspCas13b, we used the structure of PbuCas13b (PDB ID:

558 6DTD) to infer the distance between U1 RPPs and APEX2 in the RPL protein. Basically, the average

559 distances between gRNA (nucleotide 1, 12, and 23 of spacer) and the C-terminus of PbuCas13b, where

560 the APEX2 was fused to, were measured (D2). The inferred distances between APEX2 and RPPs were

561 then calculated as absolute value of the differences between D1 and D2.

563 Data availability. Raw images for western blots and raw mass spectrometry data for both U1 RPPs and 564 poly(A) RPPs are included as supporting files. 


\section{References}

567

568

569

570

571

572

573

574

575

576

577

578

579

580

581

582

583

584

585

586

587

588

589

590

591

592

593

594

595

596

597

598

599

600

601

602

603

604

605

606

607

608

609

610

611

612

613

614

615

616

617

618

619

Abudayyeh OO, Gootenberg JS, Essletzbichler P, Han S, Joung J, Belanto JJ, Verdine V, Cox DBT, Kellner MJ, Regev A, Lander ES, Voytas DF, Ting AY, Zhang F. 2017. RNA targeting with CRISPR-Cas13. Nature 550:280-284. doi:10.1038/nature24049

Baltz AG, Munschauer M, Schwanhäusser B, Vasile A, Murakawa Y, Schueler M, Youngs N, Penfold-Brown D, Drew K, Milek M, Wyler E, Bonneau R, Selbach M, Dieterich C, Landthaler M. 2012. The mRNABound Proteome and Its Global Occupancy Profile on Protein-Coding Transcripts. Molecular Cell 46:674-690. doi:10.1016/j.molcel.2012.05.021

Bandaru S, Tsuji MH, Shimizu Y, Usami K, Lee S, Takei NK, Yoshitome K, Nishimura Y, Otsuki T, Ito T. 2020. Structure-based design of gRNA for Cas13. Sci Rep 10:11610. doi:10.1038/s41598-02068459-4

Batista PJ, Chang HY. 2013. Long Noncoding RNAs: Cellular Address Codes in Development and Disease. Cell 152:1298-1307. doi:10.1016/j.cell.2013.02.012

Belousov VV, Fradkov AF, Lukyanov KA, Staroverov DB, Shakhbazov KS, Terskikh AV, Lukyanov S. 2006. Genetically encoded fluorescent indicator for intracellular hydrogen peroxide. Nat Methods 3:281286. doi:10.1038/nmeth866

Benjamini Y, Hochberg Y. 1995. Controlling the False Discovery Rate: A Practical and Powerful Approach to Multiple Testing. Journal of the Royal Statistical Society: Series B (Methodological) 57:289-300. doi:10.1111/j.2517-6161.1995.tb02031.x

Bernard JJ, Cowing-Zitron C, Nakatsuji T, Muehleisen B, Muto J, Borkowski AW, Martinez L, Greidinger EL, Yu BD, Gallo RL. 2012. Ultraviolet radiation damages self noncoding RNA and is detected by TLR3. Nat Med 18:1286-1290. doi:10.1038/nm.2861

Berretta J, Morillon A. 2009. Pervasive transcription constitutes a new level of eukaryotic genome regulation. EMBO Rep 10:973-982. doi:10.1038/embor.2009.181

Blower MD. 2013. Molecular Insights into Intracellular RNA LocalizationInternational Review of Cell and Molecular Biology. Elsevier. pp. 1-39. doi:10.1016/B978-0-12-407699-0.00001-7

Bohnsack MT, Czaplinski K, Gorlich D. 2004. Exportin 5 is a RanGTP-dependent dsRNA-binding protein that mediates nuclear export of pre-miRNAs. RNA 10:185-191. doi:10.1261/rna.5167604

Branon T, Han S, Ting A. 2017. Beyond Immunoprecipitation: Exploring New Interaction Spaces with Proximity Biotinylation. Biochemistry 56:3297-3298. doi:10.1021/acs.biochem.7b00466

Branon TC, Bosch JA, Sanchez AD, Udeshi ND, Svinkina T, Carr SA, Feldman JL, Perrimon N, Ting AY. 2018. Efficient proximity labeling in living cells and organisms with TurbolD. Nat Biotechno/ 36:880887. doi:10.1038/nbt.4201

Cai X. 2004. Human microRNAs are processed from capped, polyadenylated transcripts that can also function as mRNAs. RNA 10:1957-1966. doi:10.1261/rna.7135204

Carlevaro-Fita J, Johnson R. 2019. Global Positioning System: Understanding Long Noncoding RNAs through Subcellular Localization. Mol Cell 73:869-883. doi:10.1016/j.molcel.2019.02.008

Castello A, Fischer B, Eichelbaum K, Horos R, Beckmann BM, Strein C, Davey NE, Humphreys DT, Preiss T, Steinmetz LM, Krijgsveld J, Hentze MW. 2012. Insights into RNA biology from an atlas of mammalian mRNA-binding proteins. Cell 149:1393-1406. doi:10.1016/j.cell.2012.04.031

Caudron-Herger M, Rusin SF, Adamo ME, Seiler J, Schmid VK, Barreau E, Kettenbach AN, Diederichs S. 2019. R-DeeP: Proteome-wide and Quantitative Identification of RNA-Dependent Proteins by Density Gradient Ultracentrifugation. Mol Cell 75:184-199.e10. doi:10.1016/j.molcel.2019.04.018

Chang H, Lim J, Ha M, Kim VN. 2014. TAIL-seq: Genome-wide Determination of Poly(A) Tail Length and 3' End Modifications. Molecular Cell 53:1044-1052. doi:10.1016/j.molcel.2014.02.007

Chang Y-F, Imam JS, Wilkinson MF. 2007. The Nonsense-Mediated Decay RNA Surveillance Pathway. Annu Rev Biochem 76:51-74. doi:10.1146/annurev.biochem.76.050106.093909

Charenton C, Wilkinson ME, Nagai K. 2019. Mechanism of 5' splice site transfer for human spliceosome activation. Science 364:362-367. doi:10.1126/science.aax3289

Chen C-YA, Shyu A-B. 2011. Mechanisms of deadenylation-dependent decay: Mechanisms of deadenylation-dependent decay. WIREs RNA 2:167-183. doi:10.1002/wrna.40

Chlebowski A, Lubas M, Jensen TH, Dziembowski A. 2013. RNA decay machines: The exosome. Biochimica et Biophysica Acta (BBA) - Gene Regulatory Mechanisms 1829:552-560. doi:10.1016/j.bbagrm.2013.01.006 
Chu Ci, Spitale RC, Chang HY. 2015. Technologies to probe functions and mechanisms of long noncoding RNAs. Nat Struct Mol Biol 22:29-35. doi:10.1038/nsmb.2921

Chu C., Zhang QC, da Rocha ST, Flynn RA, Bharadwaj M, Calabrese JM, Magnuson T, Heard E, Chang HY. 2015. Systematic discovery of Xist RNA binding proteins. Cell 161:404-16. doi:10.1016/j.cell.2015.03.025

Cioni J-M, Lin JQ, Holtermann AV, Koppers M, Jakobs MAH, Azizi A, Turner-Bridger B, Shigeoka T, Franze K, Harris WA, Holt CE. 2019. Late Endosomes Act as mRNA Translation Platforms and Sustain Mitochondria in Axons. Cell 176:56-72.e15. doi:10.1016/j.cell.2018.11.030

Clément M-V, Pervaiz S. 2001. Intracellular superoxide and hydrogen peroxide concentrations: a critical balance that determines survival or death. Redox Report 6:211-214. doi:10.1179/135100001101536346

Collart MA. 2016. The Ccr4-Not complex is a key regulator of eukaryotic gene expression. Wiley Interdiscip Rev RNA 7:438-454. doi:10.1002/wrna.1332

Cox DBT, Gootenberg JS, Abudayyeh OO, Franklin B, Kellner MJ, Joung J, Zhang F. 2017. RNA editing with CRISPR-Cas13. Science 358:1019-1027. doi:10.1126/science.aaq0180

Cvitkovic I, Jurica MS. 2013. Spliceosome database: a tool for tracking components of the spliceosome. Nucleic Acids Res 41:D132-141. doi:10.1093/nar/gks999

Damgaard CK, Kahns S, Lykke-Andersen S, Nielsen AL, Jensen TH, Kjems J. 2008. A 5' Splice Site Enhances the Recruitment of Basal Transcription Initiation Factors In Vivo. Molecular Cell 29:271278. doi:10.1016/j.molcel.2007.11.035

Decker CJ, Parker R. 2012. P-Bodies and Stress Granules: Possible Roles in the Control of Translation and mRNA Degradation. Cold Spring Harbor Perspectives in Biology 4:a012286-a012286. doi:10.1101/cshperspect.a012286

Deckert J, Hartmuth K, Boehringer D, Behzadnia N, Will CL, Kastner B, Stark H, Urlaub H, Lührmann R. 2006. Protein Composition and Electron Microscopy Structure of Affinity-Purified Human Spliceosomal B Complexes Isolated under Physiological Conditions. MCB 26:5528-5543. doi:10.1128/MCB.00582-06

Derrien T, Johnson R, Bussotti G, Tanzer A, Djebali S, Tilgner H, Guernec G, Martin D, Merkel A, Knowles DG, Lagarde J, Veeravalli L, Ruan X, Ruan Y, Lassmann T, Carninci P, Brown JB, Lipovich L, Gonzalez JM, Thomas M, Davis CA, Shiekhattar R, Gingeras TR, Hubbard TJ, Notredame C, Harrow J, Guigó R. 2012. The GENCODE v7 catalog of human long noncoding RNAs: analysis of their gene structure, evolution, and expression. Genome Res 22:1775-89. doi:10.1101/gr.132159.111

Djebali S, Davis CA, Merkel A, Dobin A, Lassmann T, Mortazavi A, Tanzer A, Lagarde J, Lin W, Schlesinger F, Xue C, Marinov GK, Khatun J, Williams BA, Zaleski C, Rozowsky J, Röder M, Kokocinski F, Abdelhamid RF, Alioto T, Antoshechkin I, Baer MT, Bar NS, Batut P, Bell K, Bell I, Chakrabortty S, Chen X, Chrast J, Curado J, Derrien T, Drenkow J, Dumais E, Dumais J, Duttagupta R, Falconnet E, Fastuca M, Fejes-Toth K, Ferreira P, Foissac S, Fullwood MJ, Gao H, Gonzalez D, Gordon A, Gunawardena H, Howald C, Jha S, Johnson R, Kapranov P, King B, Kingswood C, Luo OJ, Park E, Persaud K, Preall JB, Ribeca P, Risk B, Robyr D, Sammeth M, Schaffer L, See LH, Shahab A, Skancke J, Suzuki AM, Takahashi H, Tilgner H, Trout D, Walters N, Wang H, Wrobel J, Yu Y, Ruan X, Hayashizaki Y, Harrow J, Gerstein M, Hubbard T, Reymond A, Antonarakis SE, Hannon G, Giddings MC, Ruan Y, Wold B, Carninci P, Guigó R, Gingeras TR. 2012. Landscape of transcription in human cells. Nature 489:101-8. doi:10.1038/nature11233

Dreyfus M, Régnier P. 2002. The Poly(A) Tail of mRNAs. Cell 111:611-613. doi:10.1016/S00928674(02)01137-6

Dreyfuss G, Kim VN, Kataoka N. 2002. Messenger-RNA-binding proteins and the messages they carry. Nat Rev Mol Cell Biol 3:195-205. doi:10.1038/nrm760

EIMaghraby MF, Andersen PR, Pühringer F, Hohmann U, Meixner K, Lendl T, Tirian L, Brennecke J. 2019. A Heterochromatin-Specific RNA Export Pathway Facilitates piRNA Production. Cell 178:964979.e20. doi:10.1016/j.cell.2019.07.007

Engreitz JM, Sirokman K, McDonel P, Shishkin AA, Surka C, Russell P, Grossman SR, Chow AY, Guttman M, Lander ES. 2014. RNA-RNA Interactions Enable Specific Targeting of Noncoding RNAs to Nascent Pre-mRNAs and Chromatin Sites. Cell 159:188-199. doi:10.1016/j.cell.2014.08.018

Fazal FM, Han S, Parker KR, Kaewsapsak P, Xu J, Boettiger AN, Chang HY, Ting AY. 2019. Atlas of Subcellular RNA Localization Revealed by APEX-Seq. Cell. doi:10.1016/j.cell.2019.05.027 
701

702

703

704

705

706

707

708

709

710

711

712

713

714

715

716

717

718

719

720

721

722

723

724

725

726

727

728

729

730

731

Fujiwara Y, Furuta A, Kikuchi H, Aizawa S, Hatanaka Y, Konya C, Uchida K, Yoshimura A, Tamai Y, Wada K, Kabuta T. 2013. Discovery of a novel type of autophagy targeting RNA. Autophagy 9:403-409. doi:10.4161/auto.23002

Gesteland RF. 1993. The RNA world: the nature of modern RNA suggests a prebiotic RNA world. New York: Cold Spring Harbor Laboratory Press.

Ghildiyal M, Zamore PD. 2009. Small silencing RNAs: an expanding universe. Nat Rev Genet 10:94-108. doi:10.1038/nrg2504

Gilmartin GM. 2005. Eukaryotic mRNA 3' processing: a common means to different ends. Genes Dev 19:2517-2521. doi:10.1101/gad.1378105

Glisovic T, Bachorik JL, Yong J, Dreyfuss G. 2008. RNA-binding proteins and post-transcriptional gene regulation. FEBS Lett 582:1977-1986. doi:10.1016/j.febslet.2008.03.004

Gootenberg JS, Abudayyeh OO, Kellner MJ, Joung J, Collins JJ, Zhang F. 2018. Multiplexed and portable nucleic acid detection platform with Cas13, Cas12a, and Csm6. Science 360:439-444. doi:10.1126/science.aaq0179

Graindorge A, Pinheiro I, Nawrocka A, Mallory AC, Tsvetkov P, Gil N, Carolis C, Buchholz F, Ulitsky I, Heard E, Taipale M, Shkumatava A. 2019. In-cell identification and measurement of RNA-protein interactions. Nat Commun 10:5317. doi:10.1038/s41467-019-13235-w

Guttman M, Amit I, Garber M, French C, Lin MF, Feldser D, Huarte M, Zuk O, Carey BW, Cassady JP, Cabili MN, Jaenisch R, Mikkelsen TS, Jacks T, Hacohen N, Bernstein BE, Kellis M, Regev A, Rinn JL, Lander ES. 2009. Chromatin signature reveals over a thousand highly conserved large noncoding RNAs in mammals. Nature 458:223-7. doi:10.1038/nature07672

Han S, Zhao BS, Myers SA, Carr SA, He C, Ting AY. 2020. RNA-protein interaction mapping via MS2- or Cas13-based APEX targeting. Proc Natl Acad Sci USA 202006617. doi:10.1073/pnas.2006617117

Hentze MW, Castello A, Schwarzl T, Preiss T. 2018. A brave new world of RNA-binding proteins. Nat Rev Mol Cell Biol 19:327-341. doi:10.1038/nrm.2017.130

Holt CE, Bullock SL. 2009. Subcellular mRNA Localization in Animal Cells and Why It Matters. Science 326:1212-1216. doi:10.1126/science.1176488

Huang BK, Sikes HD. 2014. Quantifying intracellular hydrogen peroxide perturbations in terms of concentration. Redox Biology 2:955-962. doi:10.1016/j.redox.2014.08.001

Huang Y, Carmichael GG. 1996. Role of polyadenylation in nucleocytoplasmic transport of mRNA. Mol Cell Biol 16:1534-1542. doi:10.1128/MCB.16.4.1534

Huang Y, Guo Q, Ding X-P, Wang X. 2020. Mechanism of long noncoding RNAs as transcriptional regulators in cancer. RNA Biology 1-13. doi:10.1080/15476286.2019.1710405

International Human Genome Sequencing Consortium. 2001. Initial sequencing and analysis of the human genome. Nature 409:860-921. doi:10.1038/35057062

lyer MK, Niknafs YS, Malik R, Singhal U, Sahu A, Hosono Y, Barrette TR, Prensner JR, Evans JR, Zhao S, Poliakov A, Cao X, Dhanasekaran SM, Wu Y-M, Robinson DR, Beer DG, Feng FY, lyer HK, Chinnaiyan AM. 2015. The landscape of long noncoding RNAs in the human transcriptome. Nat Genet 47:199-208. doi:10.1038/ng.3192

Kadaba S, Wang X, Anderson JT. 2006. Nuclear RNA surveillance in Saccharomyces cerevisiae: Trf4pdependent polyadenylation of nascent hypomethylated tRNA and an aberrant form of 5S rRNA. RNA 12:508-521. doi:10.1261/rna.2305406

Kim DI, Jensen SC, Noble KA, Kc B, Roux KH, Motamedchaboki K, Roux KJ. 2016. An improved smaller biotin ligase for BiolD proximity labeling. MBoC 27:1188-1196. doi:10.1091/mbc.E15-12-0844

Kim VN. 2005. MicroRNA biogenesis: coordinated cropping and dicing. Nat Rev Mol Cell Biol 6:376-385. doi:10.1038/nrm1644

Kneuss E, Munafò M, Eastwood EL, Deumer U-S, Preall JB, Hannon GJ, Czech B. 2019. Specialization of the Drosophila nuclear export family protein Nxf3 for piRNA precursor export. Genes Dev 33:12081220. doi:10.1101/gad.328690.119

Köhler A, Hurt E. 2007. Exporting RNA from the nucleus to the cytoplasm. Nat Rev Mol Cell Biol 8:761773. doi:10.1038/nrm2255

Konermann S, Lotfy P, Brideau NJ, Oki J, Shokhirev MN, Hsu PD. 2018. Transcriptome Engineering with RNA-Targeting Type VI-D CRISPR Effectors. Cell 173:665-676.e14. doi:10.1016/j.cell.2018.02.033

Kopp F, Mendell JT. 2018. Functional Classification and Experimental Dissection of Long Noncoding RNAs. Cell 172:393-407. doi:10.1016/j.cell.2018.01.011 
Kruse C, Willkomm DK, Grünweller A, Vollbrandt T, Sommer S, Busch S, Pfeiffer T, Brinkmann J, Hartmann RK, Müller PK. 2000. Export and transport of tRNA are coupled to a multi-protein complex. Biochem $J 346$ Pt 1:107-115.

Kwek KY, Murphy S, Furger A, Thomas B, O'Gorman W, Kimura H, Proudfoot NJ, Akoulitchev A. 2002. U1 snRNA associates with TFIIH and regulates transcriptional initiation. Nat Struct Biol. doi:10.1038/nsb862

Kwon SC, Yi H, Eichelbaum K, Föhr S, Fischer B, You KT, Castello A, Krijgsveld J, Hentze MW, Kim VN. 2013. The RNA-binding protein repertoire of embryonic stem cells. Nat Struct Mol Biol 20:11221130. doi:10.1038/nsmb.2638

Lai W-JC, Kayedkhordeh M, Cornell EV, Farah E, Bellaousov S, Rietmeijer R, Salsi E, Mathews DH, Ermolenko DN. 2018. mRNAs and IncRNAs intrinsically form secondary structures with short endto-end distances. Nat Commun 9:4328. doi:10.1038/s41467-018-06792-z

Lam SS, Martell JD, Kamer KJ, Deerinck TJ, Ellisman MH, Mootha VK, Ting AY. 2015. Directed evolution of APEX2 for electron microscopy and proximity labeling. Nat Methods 12:51-54. doi:10.1038/nmeth.3179

Laprade H, Querido E, Smith MJ, Guérit D, Crimmins H, Conomos D, Pourret E, Chartrand P, Sfeir A. 2020. Single-Molecule Imaging of Telomerase RNA Reveals a Recruitment-Retention Model for Telomere Elongation. Molecular Cell 79:115-126.e6. doi:10.1016/j.molcel.2020.05.005

Laroia G, Cuesta R, Brewer G, Schneider RJ. 1999. Control of mRNA decay by heat shock-ubiquitinproteasome pathway. Science 284:499-502. doi:10.1126/science.284.5413.499

Laroia G, Sarkar B, Schneider RJ. 2002. Ubiquitin-dependent mechanism regulates rapid turnover of AUrich cytokine mRNAs. Proc Natl Acad Sci USA 99:1842-1846. doi:10.1073/pnas.042575699

Lebbink RJ, Lowe M, Chan T, Khine H, Wang X, McManus MT. 2011. Polymerase II promoter strength determines efficacy of microRNA adapted shRNAs. PLoS ONE 6:e26213. doi:10.1371/journal.pone.0026213

Leija-Martínez N, Casas-Flores S, Cadena-Nava RD, Roca JA, Mendez-Cabañas JA, Gomez E, RuizGarcia J. 2014. The separation between the 5'-3' ends in long RNA molecules is short and nearly constant. Nucleic Acids Research 42:13963-13968. doi:10.1093/nar/gku1249

Lemmens I, Jansen S, de Rouck S, de Smet A-S, Defever D, Neyts J, Dallmeier K, Tavernier J. 2020. The Development of RNA-KISS, a Mammalian Three-Hybrid Method to Detect RNA-Protein Interactions in Living Mammalian Cells. J Proteome Res acs.jproteome.0c00068. doi:10.1021/acs.jproteome.0c00068

Li J-H, Liu S, Zhou H, Qu L-H, Yang J-H. 2014. starBase v2.0: decoding miRNA-ceRNA, miRNA-ncRNA and protein-RNA interaction networks from large-scale CLIP-Seq data. Nucl Acids Res 42:D92D97. doi:10.1093/nar/gkt1248

Li X, Fu X-D. 2019. Chromatin-associated RNAs as facilitators of functional genomic interactions. Nat Rev Genet. doi:10.1038/s41576-019-0135-1

Li XZ, Roy CK, Dong X, Bolcun-Filas E, Wang J, Han BW, Xu J, Moore MJ, Schimenti JC, Weng Z, Zamore PD. 2013. An ancient transcription factor initiates the burst of piRNA production during early meiosis in mouse testes. Mol Cell 50:67-81. doi:10.1016/j.molcel.2013.02.016

Li Y, Liu S, Cao L, Luo Y, Du H, Li S, You F. 2020. CBRPP: a new RNA-centric method to study RNAprotein interactions (preprint). Molecular Biology. doi:10.1101/2020.04.09.033290

Licatalosi DD, Mele A, Fak JJ, Ule J, Kayikci M, Chi SW, Clark TA, Schweitzer AC, Blume JE, Wang X, Darnell JC, Darnell RB. 2008. HITS-CLIP yields genome-wide insights into brain alternative RNA processing. Nature 456:464-469. doi:10.1038/nature07488

Lim J, Kim D, Lee Y, Ha M, Lee M, Yeo J, Chang H, Song J, Ahn K, Kim VN. 2018. Mixed tailing by TENT4A and TENT4B shields mRNA from rapid deadenylation. Science 361:701-704. doi:10.1126/science.aam5794

Lin X, Spindler TJ, de Souza Fonseca MA, Corona RI, Seo J-H, Dezem FS, Li L, Lee JM, Long HW, Sellers TA, Karlan BY, Noushmehr H, Freedman ML, Gayther SA, Lawrenson K. 2019. Super-EnhancerAssociated LncRNA UCA1 Interacts Directly with AMOT to Activate YAP Target Genes in Epithelial Ovarian Cancer. iScience 17:242-255. doi:10.1016/j.isci.2019.06.025

Liu Q, Zheng J, Sun W, Huo Y, Zhang L, Hao P, Wang H, Zhuang M. 2018. A proximity-tagging system to identify membrane protein-protein interactions. Nat Methods 15:715-722. doi:10.1038/s41592018-0100-5 
Lund E, Güttinger S, Calado A, Dahlberg JE, Kutay U. 2004. Nuclear export of microRNA precursors. Science 303:95-98. doi:10.1126/science.1090599

Lunde BM, Moore C, Varani G. 2007. RNA-binding proteins: modular design for efficient function. Nat Rev Mol Cell Biol 8:479-490. doi:10.1038/nrm2178

Lyublinskaya O, Antunes F. 2019. Measuring intracellular concentration of hydrogen peroxide with the use of genetically encoded $\mathrm{H} 2 \mathrm{O} 2$ biosensor HyPer. Redox Biology 24:101200. doi:10.1016/j.redox.2019.101200

Malone CD, Hannon GJ. 2009. Small RNAs as guardians of the genome. Cell 136:656-668. doi:10.1016/j.cell.2009.01.045

McHugh CA, Chen CK, Chow A, Surka CF, Tran C, McDonel P, Pandya-Jones A, Blanco M, Burghard C, Moradian A, Sweredoski MJ, Shishkin AA, Su J, Lander ES, Hess S, Plath K, Guttman M. 2015. The Xist IncRNA interacts directly with SHARP to silence transcription through HDAC3. Nature 521:232-6. doi:10.1038/nature14443

Metkar M, Ozadam H, Lajoie BR, Imakaev M, Mirny LA, Dekker J, Moore MJ. 2018. Higher-Order Organization Principles of Pre-translational mRNPs. Molecular Cell 72:715-726.e3. doi:10.1016/j.molcel.2018.09.012

Milek M, Imami K, Mukherjee N, Bortoli FD, Zinnall U, Hazapis O, Trahan C, Oeffinger M, Heyd F, Ohler U, Selbach M, Landthaler M. 2017. DDX54 regulates transcriptome dynamics during DNA damage response. Genome Res 27:1344-1359. doi:10.1101/gr.218438.116

Mofatteh M, Bullock SL. 2017. SnapShot: Subcellular mRNA Localization. Cell 169:178-178.e1. doi:10.1016/j.cell.2017.03.004

Mugridge JS, Coller J, Gross JD. 2018. Structural and molecular mechanisms for the control of eukaryotic 5'-3' mRNA decay. Nat Struct Mol Biol 25:1077-1085. doi:10.1038/s41594-018-0164-z

Muhlrad D, Decker CJ, Parker R. 1994. Deadenylation of the unstable mRNA encoded by the yeast MFA2 gene leads to decapping followed by 5'-->3' digestion of the transcript. Genes Dev 8:855-866. doi:10.1101/gad.8.7.855

Mukherjee J, Hermesh O, Eliscovich C, Nalpas N, Franz-Wachtel M, Maček B, Jansen R-P. 2019. $\beta$-Actin mRNA interactome mapping by proximity biotinylation. Proc Natl Acad Sci USA 116:12863-12872. doi:10.1073/pnas.1820737116

Munro S. 2011. The Golgin Coiled-Coil Proteins of the Golgi Apparatus. Cold Spring Harbor Perspectives in Biology 3:a005256-a005256. doi:10.1101/cshperspect.a005256

Norbury CJ. 2013. Cytoplasmic RNA: a case of the tail wagging the dog. Nat Rev Mol Cell Biol 14:643-653. doi:10.1038/nrm3645

Okamura M, Inose H, Masuda S. 2015. RNA Export through the NPC in Eukaryotes. Genes 6:124-149. doi:10.3390/genes6010124

Padrón A, Iwasaki S, Ingolia NT. 2019. Proximity RNA Labeling by APEX-Seq Reveals the Organization of Translation Initiation Complexes and Repressive RNA Granules. Molecular Cell 75:875-887.e5. doi:10.1016/j.molcel.2019.07.030

Palacios I. 1997. Nuclear import of U snRNPs requires importin beta. The EMBO Journal 16:6783-6792. doi:10.1093/emboj/16.22.6783

Panhale A, Richter FM, Ramírez F, Shvedunova M, Manke T, Mittler G, Akhtar A. 2019. CAPRI enables comparison of evolutionarily conserved RNA interacting regions. Nat Commun 10:2682. doi:10.1038/s41467-019-10585-3

Pomeranz Krummel DA, Oubridge C, Leung AKW, Li J, Nagai K. 2009. Crystal structure of human spliceosomal U1 snRNP at $5.5 \AA$ resolution. Nature 458:475-480. doi:10.1038/nature07851

Queiroz RML, Smith T, Villanueva E, Marti-Solano M, Monti M, Pizzinga M, Mirea D-M, Ramakrishna M, Harvey RF, Dezi V, Thomas GH, Willis AE, Lilley KS. 2019. Comprehensive identification of RNAprotein interactions in any organism using orthogonal organic phase separation (OOPS). Nat Biotechnol 37:169-178. doi:10.1038/s41587-018-0001-2

Quinn JJ, Ilik IA, Qu K, Georgiev P, Chu C, Akhtar A, Chang HY. 2014. Revealing long noncoding RNA architecture and functions using domain-specific chromatin isolation by RNA purification. Nat Biotechnol 32:933-940. doi:10.1038/nbt.2943

Ramanathan M, Majzoub K, Rao DS, Neela PH, Zarnegar BJ, Mondal S, Roth JG, Gai H, Kovalski JR, Siprashvili Z, Palmer TD, Carette JE, Khavari PA. 2018. RNA-protein interaction detection in living cells. Nat Methods 15:207-212. doi:10.1038/nmeth.4601 
842

843

844

845

846

847

848

849

850

851

852

853

854

855

856

857

858

859

860

861

862

863

864

865

866

867

868

869

870

871

872

873

874

875

876

877

878

879

880

881

882

883

884

885

886

887

888

889

890

891

892

893

894

895

896

Ramanathan M, Porter DF, Khavari PA. 2019. Methods to study RNA-protein interactions. Nat Methods 16:225-234. doi:10.1038/s41592-019-0330-1

Rauch S, He E, Srienc M, Zhou H, Zhang Z, Dickinson BC. 2019. Programmable RNA-Guided RNA Effector Proteins Built from Human Parts. Cell S0092867419306208. doi:10.1016/j.cell.2019.05.049

Rhee H-W, Zou P, Udeshi ND, Martell JD, Mootha VK, Carr SA, Ting AY. 2013. Proteomic Mapping of Mitochondria in Living Cells via Spatially Restricted Enzymatic Tagging. Science 339:1328-1331. doi:10.1126/science.1230593

Roux KJ, Kim DI, Burke B. 2013. BiolD: a screen for protein-protein interactions. Curr Protoc Protein Sci 74:19.23.1-19.23.14. doi:10.1002/0471140864.ps1923s74

Roux KJ, Kim DI, Raida M, Burke B. 2012. A promiscuous biotin ligase fusion protein identifies proximal and interacting proteins in mammalian cells. Journal of Cell Biology 196:801-810. doi:10.1083/jcb.201112098

Samavarchi-Tehrani P, Samson R, Gingras A-C. 2020. Proximity Dependent Biotinylation: Key Enzymes and Adaptation to Proteomics Approaches. Mol Cell Proteomics 19:757-773. doi:10.1074/mcp.R120.001941

Schrodinger. 2015. The PyMOL Molecular Graphics System, Version 1.8.

Shi Y, Manley JL. 2015. The end of the message: multiple protein-RNA interactions define the mRNA polyadenylation site. Genes Dev 29:889-897. doi:10.1101/gad.261974.115

Simon AE, Miller WA. 2013. 3' cap-independent translation enhancers of plant viruses. Annu Rev Microbiol 67:21-42. doi:10.1146/annurev-micro-092412-155609

Smargon AA, Cox DBT, Pyzocha NK, Zheng K, Slaymaker IM, Gootenberg JS, Abudayyeh OA, Essletzbichler P, Shmakov S, Makarova KS, Koonin EV, Zhang F. 2017. Cas13b Is a Type VI-B CRISPR-Associated RNA-Guided RNase Differentially Regulated by Accessory Proteins Csx27 and Csx28. Mol Cell 65:618-630.e7. doi:10.1016/j.molcel.2016.12.023

Smyth GK. 2004. Linear Models and Empirical Bayes Methods for Assessing Differential Expression in Microarray Experiments. Statistical Applications in Genetics and Molecular Biology 3:1-25. doi:10.2202/1544-6115.1027

So BR, Di C, Cai Z, Venters CC, Guo J, Oh J-M, Arai C, Dreyfuss G. 2019. A Complex of U1 snRNP with Cleavage and Polyadenylation Factors Controls Telescripting, Regulating mRNA Transcription in Human Cells. Molecular Cell 76:590-599.e4. doi:10.1016/j.molcel.2019.08.007

Spiluttini B, Gu B, Belagal P, Smirnova AS, Nguyen VT, Hebert C, Schmidt U, Bertrand E, Darzacq X, Bensaude O. 2010. Splicing-independent recruitment of U1 snRNP to a transcription unit in living cells. Journal of Cell Science 123:2085-2093. doi:10.1242/jcs.061358

Spitale RC, Flynn RA, Zhang QC, Crisalli P, Lee B, Jung J-W, Kuchelmeister HY, Batista PJ, Torre EA, Kool ET, Chang HY. 2015. Structural imprints in vivo decode RNA regulatory mechanisms. Nature 519:486-490. doi:10.1038/nature14263

Stark H, Dube P, Lührmann R, Kastner B. 2001. Arrangement of RNA and proteins in the spliceosomal U1 small nuclear ribonucleoprotein particle. Nature 409:539-542. doi:10.1038/35054102

Sun L, Fazal FM, Li P, Broughton JP, Lee B, Tang L, Huang W, Kool ET, Chang HY, Zhang QC. 2019. RNA structure maps across mammalian cellular compartments. Nat Struct Mol Biol 26:322-330. doi:10.1038/s41594-019-0200-7

Szklarczyk D, Gable AL, Lyon D, Junge A, Wyder S, Huerta-Cepas J, Simonovic M, Doncheva NT, Morris JH, Bork P, Jensen LJ, Mering C von. 2019. STRING v11: protein-protein association networks with increased coverage, supporting functional discovery in genome-wide experimental datasets. Nucleic Acids Res 47:D607-D613. doi:10.1093/nar/gky1131

Tarn W-Y, Chang T-H. 2009. The current understanding of Ded1p/DDX3 homologs from yeast to human. RNA Biology 6:17-20. doi:10.4161/rna.6.1.7440

Tian B. 2005. A large-scale analysis of mRNA polyadenylation of human and mouse genes. Nucleic Acids Research 33:201-212. doi:10.1093/nar/gki158

Trendel J, Schwarzl T, Horos R, Prakash A, Bateman A, Hentze MW, Krijgsveld J. 2019. The Human RNABinding Proteome and Its Dynamics during Translational Arrest. Cell 176:391-403.e19. doi:10.1016/j.cell.2018.11.004

Truniger V, Miras M, Aranda MA. 2017. Structural and Functional Diversity of Plant Virus 3'-CapIndependent Translation Enhancers (3'-CITEs). Front Plant Sci 8:2047. doi:10.3389/fpls.2017.02047 
Urdaneta EC, Beckmann BM. 2019. Fast and unbiased purification of RNA-protein complexes after UV cross-linking. Methods S1046202318304869. doi:10.1016/j.ymeth.2019.09.013

Van Nostrand EL, Pratt GA, Shishkin AA, Gelboin-Burkhart C, Fang MY, Sundararaman B, Blue SM, Nguyen TB, Surka C, Elkins K, Stanton R, Rigo F, Guttman M, Yeo GW. 2016. Robust transcriptome-wide discovery of RNA-binding protein binding sites with enhanced CLIP (eCLIP). Nat Methods 13:508-514. doi:10.1038/nmeth.3810

Venter JC, Adams MD, Myers EW, Li PW, Mural RJ, Sutton GG, Smith HO, Yandell M, Evans CA, Holt RA, Gocayne JD, Amanatides P, Ballew RM, Huson DH, Wortman JR, Zhang Q, Kodira CD, Zheng XH, Chen L, Skupski M, Subramanian G, Thomas PD, Zhang J, Gabor Miklos GL, Nelson C, Broder S, Clark AG, Nadeau J, McKusick VA, Zinder N, Levine AJ, Roberts RJ, Simon M, Slayman C, Hunkapiller M, Bolanos R, Delcher A, Dew I, Fasulo D, Flanigan M, Florea L, Halpern A, Hannenhalli S, Kravitz S, Levy S, Mobarry C, Reinert K, Remington K, Abu-Threideh J, Beasley E, Biddick K, Bonazzi V, Brandon R, Cargill M, Chandramouliswaran I, Charlab R, Chaturvedi K, Deng Z, Francesco VD, Dunn P, Eilbeck K, Evangelista C, Gabrielian AE, Gan W, Ge W, Gong F, Gu Z, Guan P, Heiman TJ, Higgins ME, Ji R-R, Ke Z, Ketchum KA, Lai Z, Lei Y, Li Z, Li J, Liang Y, Lin X, Lu F, Merkulov GV, Milshina N, Moore HM, Naik AK, Narayan VA, Neelam B, Nusskern D, Rusch DB, Salzberg S, Shao W, Shue B, Sun J, Wang ZY, Wang A, Wang X, Wang J, Wei M-H, Wides R, Xiao C, Yan C, Yao A, Ye J, Zhan M, Zhang W, Zhang H, Zhao Q, Zheng L, Zhong F, Zhong W, Zhu SC, Zhao S, Gilbert D, Baumhueter S, Spier G, Carter C, Cravchik A, Woodage T, Ali F, An H, Awe A, Baldwin D, Baden H, Barnstead M, Barrow I, Beeson K, Busam D, Carver A, Center A, Cheng ML, Curry L, Danaher S, Davenport L, Desilets R, Dietz S, Dodson K, Doup L, Ferriera S, Garg N, Gluecksmann A, Hart B, Haynes J, Haynes C, Heiner C, Hladun S, Hostin D, Houck J, Howland T, Ibegwam C, Johnson J, Kalush F, Kline L, Koduru S, Love A, Mann F, May D, McCawley S, Mclntosh T, McMullen I, Moy M, Moy L, Murphy B, Nelson K, Pfannkoch C, Pratts E, Puri V, Qureshi H, Reardon M, Rodriguez R, Rogers Y-H, Romblad D, Ruhfel B, Scott R, Sitter C, Smallwood M, Stewart E, Strong R, Suh E, Thomas R, Tint NN, Tse S, Vech C, Wang G, Wetter J, Williams S, Williams M, Windsor S, Winn-Deen E, Wolfe K, Zaveri J, Zaveri K, Abril JF, Guigó R, Campbell MJ, Sjolander KV, Karlak B, Kejariwal A, Mi H, Lazareva B, Hatton T, Narechania A, Diemer K, Muruganujan A, Guo N, Sato S, Bafna V, Istrail S, Lippert R, Schwartz R, Walenz B, Yooseph S, Allen D, Basu A, Baxendale J, Blick L, Caminha M, Carnes-Stine J, Caulk P, Chiang Y-H, Coyne M, Dahlke C, Mays AD, Dombroski M, Donnelly M, Ely D, Esparham S, Fosler C, Gire H, Glanowski S, Glasser K, Glodek A, Gorokhov M, Graham K, Gropman B, Harris M, Heil J, Henderson S, Hoover J, Jennings D, Jordan C, Jordan J, Kasha J, Kagan L, Kraft C, Levitsky A, Lewis M, Liu X, Lopez J, Ma D, Majoros W, McDaniel J, Murphy S, Newman M, Nguyen T, Nguyen N, Nodell M, Pan S, Peck J, Peterson M, Rowe W, Sanders R, Scott J, Simpson M, Smith T, Sprague A, Stockwell T, Turner R, Venter E, Wang M, Wen M, Wu D, Wu M, Xia A, Zandieh A, Zhu X. 2001. The Sequence of the Human Genome. Science 291:1304-1351. doi:10.1126/science. 1058040

Weber G, Trowitzsch S, Kastner B, Lührmann R, Wahl MC. 2010. Functional organization of the Sm core in the crystal structure of human U1 snRNP. EMBO J 29:4172-4184. doi:10.1038/emboj.2010.295

Wessels H-H, Méndez-Mancilla A, Guo X, Legut M, Daniloski Z, Sanjana NE. 2020. Massively parallel Cas13 screens reveal principles for guide RNA design. Nat Biotechnol. doi:10.1038/s41587-0200456-9

Wilk R, Hu J, Blotsky D, Krause HM. 2016. Diverse and pervasive subcellular distributions for both coding and long noncoding RNAs. Genes Dev 30:594-609. doi:10.1101/gad.276931.115

Wurtmann EJ, Wolin SL. 2009. RNA under attack: cellular handling of RNA damage. Crit Rev Biochem Mol Biol 44:34-49. doi:10.1080/10409230802594043

Yamashita A, Chang T-C, Yamashita Y, Zhu W, Zhong Z, Chen C-YA, Shyu A-B. 2005. Concerted action of poly(A) nucleases and decapping enzyme in mammalian mRNA turnover. Nat Struct Mol Biol 12:1054-1063. doi:10.1038/nsmb1016

Yan WX, Chong S, Zhang H, Makarova KS, Koonin EV, Cheng DR, Scott DA. 2018. Cas13d Is a Compact RNA-Targeting Type VI CRISPR Effector Positively Modulated by a WYL-Domain-Containing Accessory Protein. Mol Cell 70:327-339.e5. doi:10.1016/j.molcel.2018.02.028

Yan Y-B. 2014. Deadenylation: enzymes, regulation, and functional implications: Regulation of deadenylation. WIREs RNA 5:421-443. doi:10.1002/wrna.1221 
952

953

954

955

956

957

958

959

960

961

962

963

964

965

966

967

968

969

970

971

972

973

974

975

976

977

978

979

980

981

982

Yang L, Duff MO, Graveley BR, Carmichael GG, Chen L-L. 2011. Genomewide characterization of nonpolyadenylated RNAs. Genome Biol 12:R16. doi:10.1186/gb-2011-12-2-r16

Yang L, Froberg JE, Lee JT. 2014. Long noncoding RNAs: fresh perspectives into the RNA world. Trends in Biochemical Sciences 39:35-43. doi:10.1016/j.tibs.2013.10.002

Yang L-Z, Wang Y, Li S-Q, Yao R-W, Luan P-F, Wu H, Carmichael GG, Chen L-L. 2019. Dynamic Imaging of RNA in Living Cells by CRISPR-Cas13 Systems. Molecular Cell 76:981-997.e7. doi:10.1016/j.molcel.2019.10.024

Yi R, Qin Y, Macara IG, Cullen BR. 2003. Exportin-5 mediates the nuclear export of pre-microRNAs and short hairpin RNAs. Genes Dev 17:3011-3016. doi:10.1101/gad.1158803

Yi W, Li J, Zhu X, Wang X, Fan L, Sun W, Liao L, Zhang J, Li X, Ye J, Chen F, Taipale J, Chan KM, Zhang L, Yan J. 2020. CRISPR-assisted detection of RNA-protein interactions in living cells. Nat Methods. doi:10.1038/s41592-020-0866-0

Yin Y, Lu JY, Zhang X, Shao W, Xu Y, Li P, Hong Y, Cui L, Shan G, Tian B, Zhang QC, Shen X. 2020. U1 snRNP regulates chromatin retention of noncoding RNAs. Nature 580:147-150. doi:10.1038/s41586-020-2105-3

Yu Y, Reed R. 2015. FUS functions in coupling transcription to splicing by mediating an interaction between RNAP II and U1 snRNP. Proc Natl Acad Sci USA 112:8608-8613. doi:10.1073/pnas.1506282112

Zhang C, Konermann S, Brideau NJ, Lotfy P, Wu X, Novick SJ, Strutzenberg T, Griffin PR, Hsu PD, Lyumkis D. 2018. Structural Basis for the RNA-Guided Ribonuclease Activity of CRISPR-Cas13d. Cell 175:212-223.e17. doi:10.1016/j.cell.2018.09.001

Zhang Z, Sun W, Shi T, Lu P, Zhuang M, Liu J-L. 2020. Capturing RNA-protein interaction via CRUIS. Nucleic Acids Research gkaa143. doi:10.1093/nar/gkaa143

Zhou B, Wang Y, Yan Y, Mariscal J, Di Vizio D, Freeman MR, Yang W. 2019. Low-Background Acyl-Biotinyl Exchange Largely Eliminates the Coisolation of Non- S -Acylated Proteins and Enables Deep S Acylproteomic Analysis. Anal Chem 91:9858-9866. doi:10.1021/acs.analchem.9b01520

Zhou Y, Wang G, Wang P, Li Z, Yue T, Wang J, Zou P. 2019. Expanding APEX2 Substrates for ProximityDependent Labeling of Nucleic Acids and Proteins in Living Cells. Angew Chem Int Ed 58:1176311767. doi:10.1002/anie.201905949

Zhou Z, Licklider LJ, Gygi SP, Reed R. 2002. Comprehensive proteomic analysis of the human spliceosome. Nature 419:182-185. doi:10.1038/nature01031 
A

RNA proximal

protein proteins (RPPs)

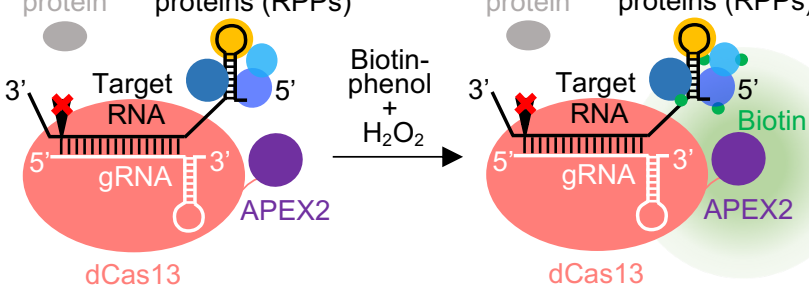

B

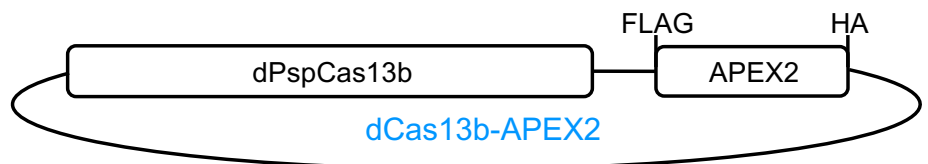

C

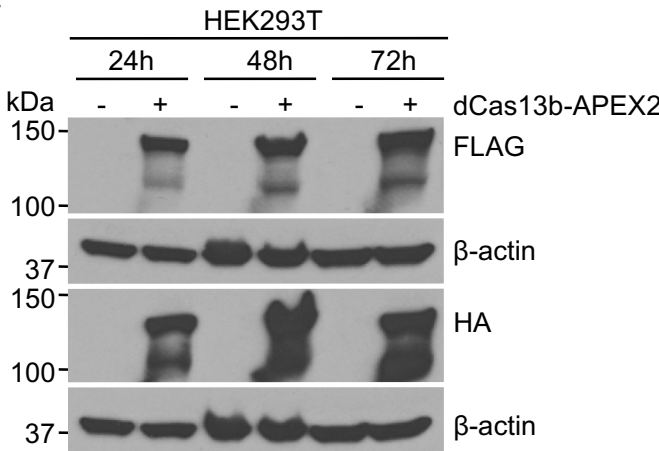

D HEK293T

$+$ dCas13b-APEX2

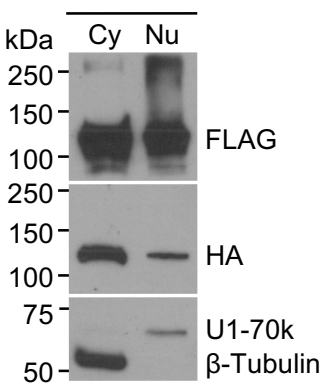

Enriching biotinylated

RPPs

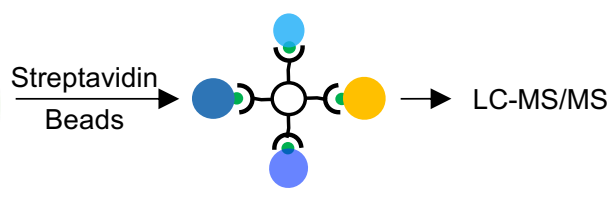

E

HEK293T dCas13b-APEX2

$+\quad+\quad-\quad+\quad \mathrm{BP}$

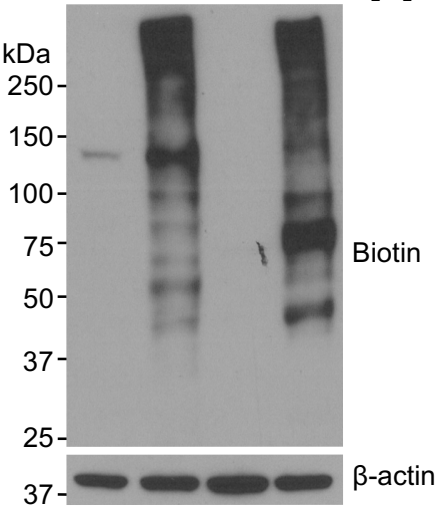

Fig. 1 


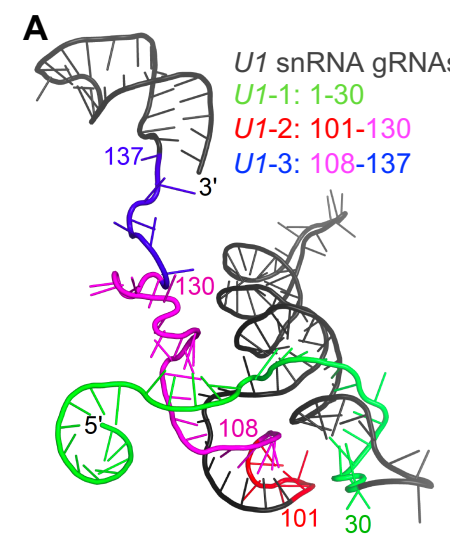

C

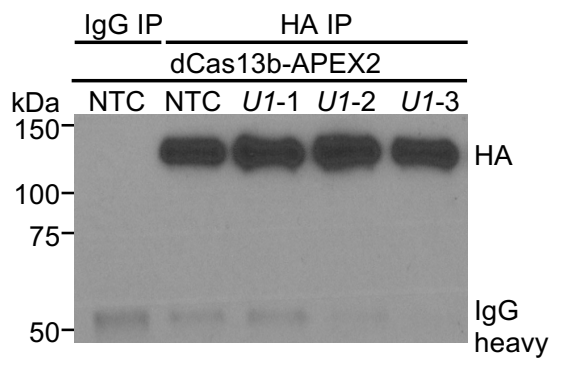

B 1.6

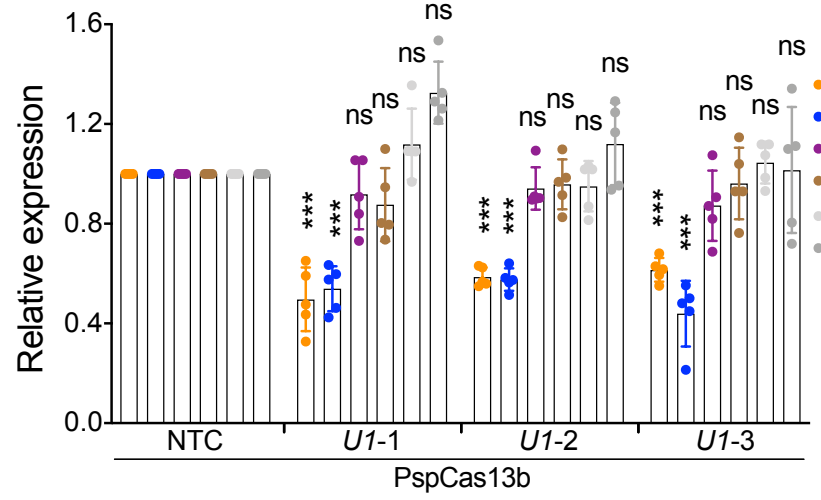

D

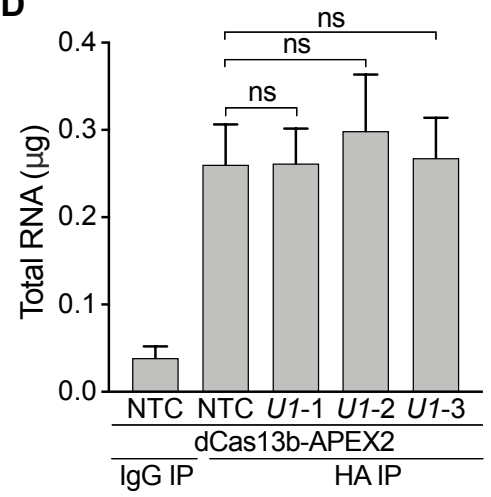

E

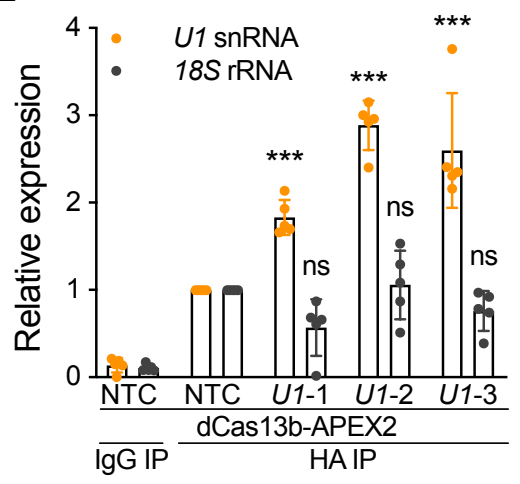

Fig. 2 
A

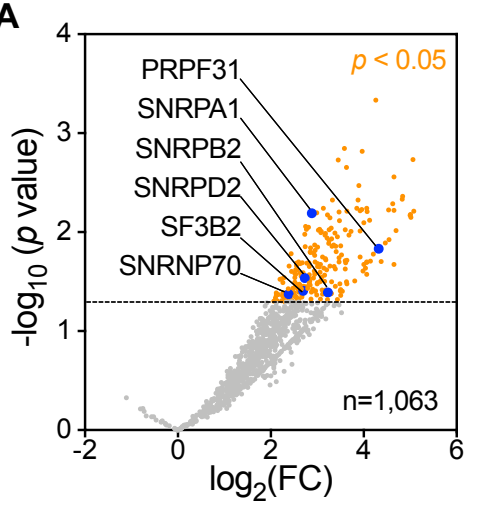

D
B

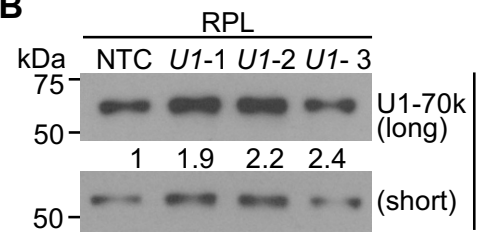

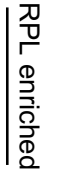

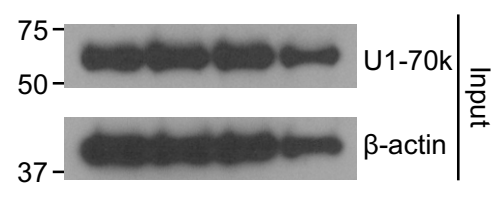

C

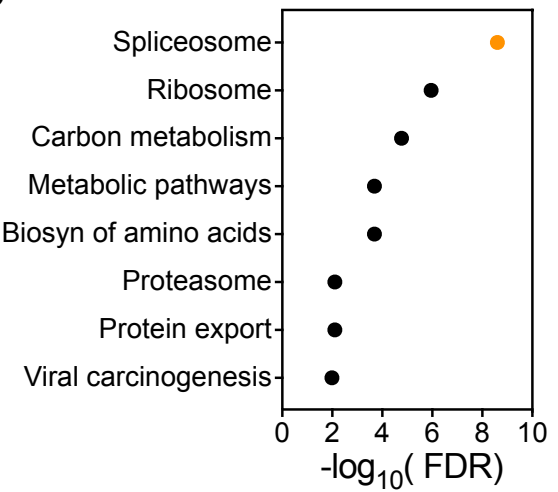

E

\begin{tabular}{ccccc}
\hline RBP & Gene Name & Cluster \# & CLIP Exp \# & CLIP ID \# \\
\hline DDX3X & RNU1-1 & 1 & 3 & 3 \\
SRSF3 & RNU1-1 & 2 & 2 & 3 \\
SRSF1 & RNU1-1 & 4 & 5 & 7 \\
YTHDC1 & RNU1-1 & 1 & 2 & 2 \\
\hline
\end{tabular}

$\mathbf{F}$

\begin{tabular}{|l|r|}
$\begin{array}{l}\text { RNA splicing } \\
99 \text { splicing \& } \\
\text { related factors }\end{array}$ & $\begin{array}{r}\text { Chromatin } \\
\text { ncRNAs } \\
\text { retention }\end{array}$ \\
\hline & U1 RPPs \\
\hline $\begin{array}{l}\text { Nuclear } \\
\text { import }\end{array}$ & $\begin{array}{r}\text { Transcription } \\
\text { initiation } \\
\text { KPNB1 }\end{array}$ \\
GTF2F2
\end{tabular}

G

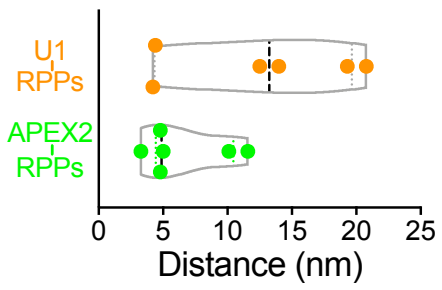

Fig. 3 
A
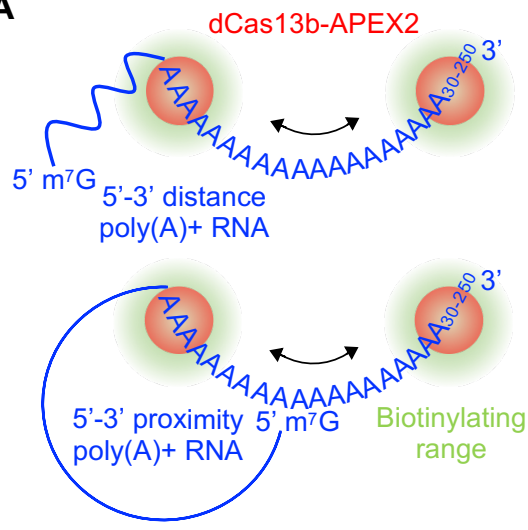

C

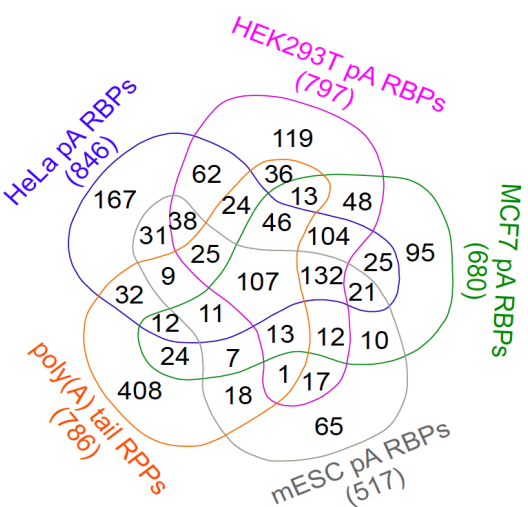

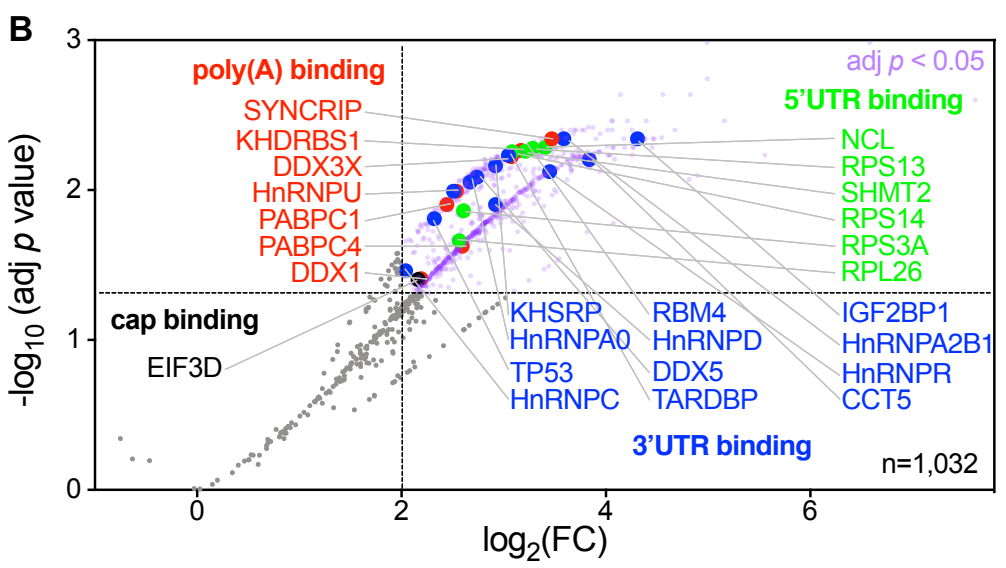

D

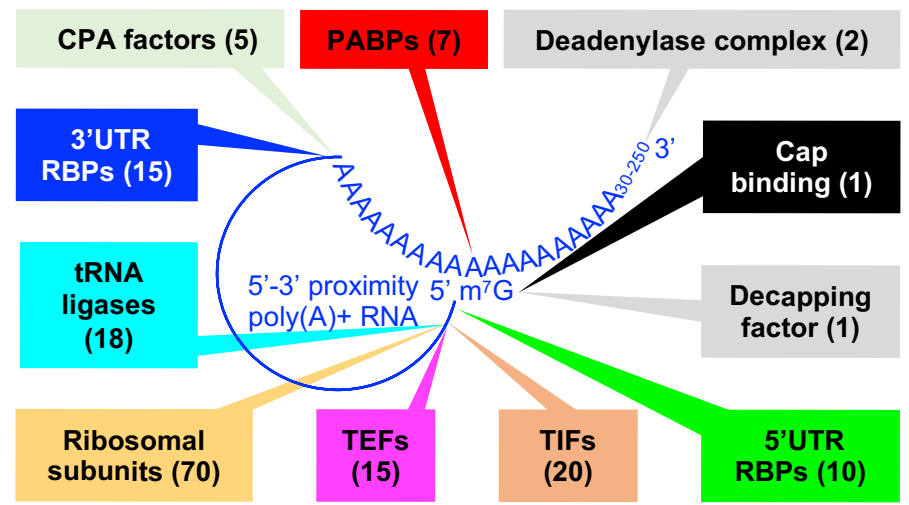

Fig. 4 


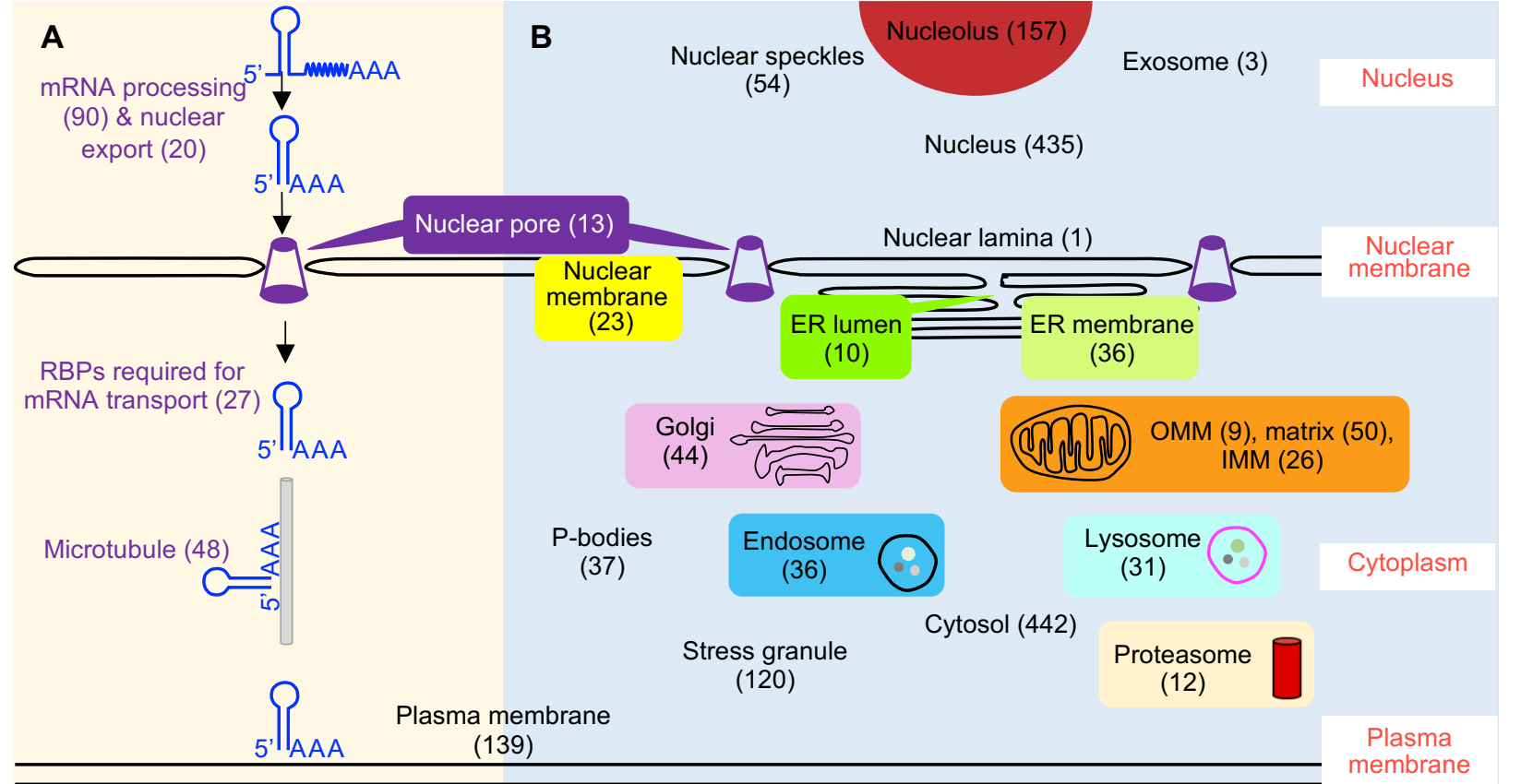

Fig. 5 


\section{Raw western blot data}

Figure 1C

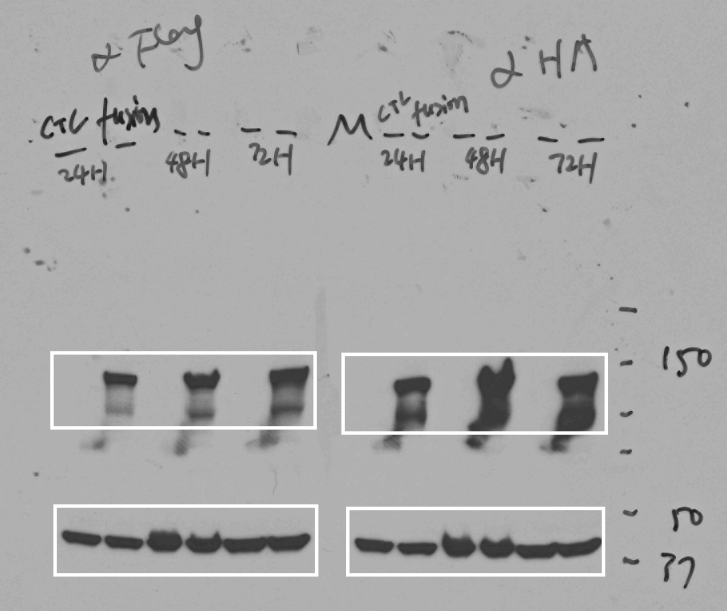

Figure 3B
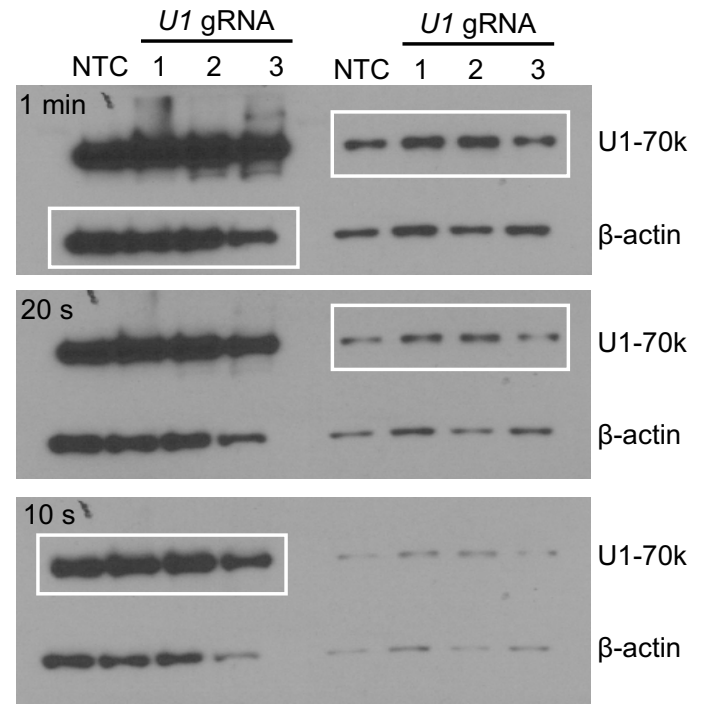

Whole cell lysate

Streptavidin enriched

U1-70k

$\beta$-actin

U1-70k

$\beta$-actin
Figure 1D

Cy $\mathrm{Nu}$ Cy $\mathrm{Nu}$

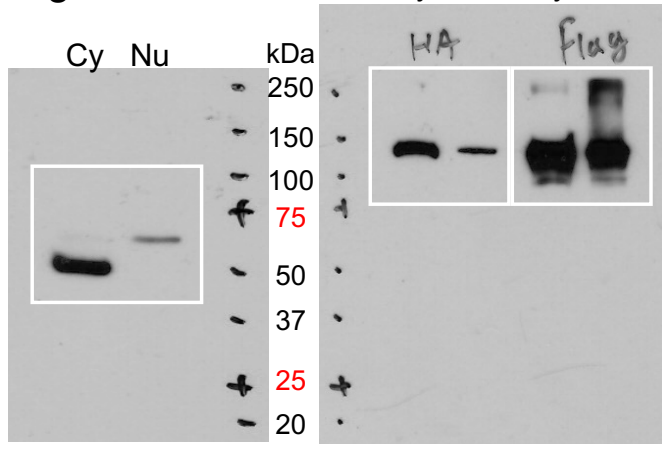

Figure 1E

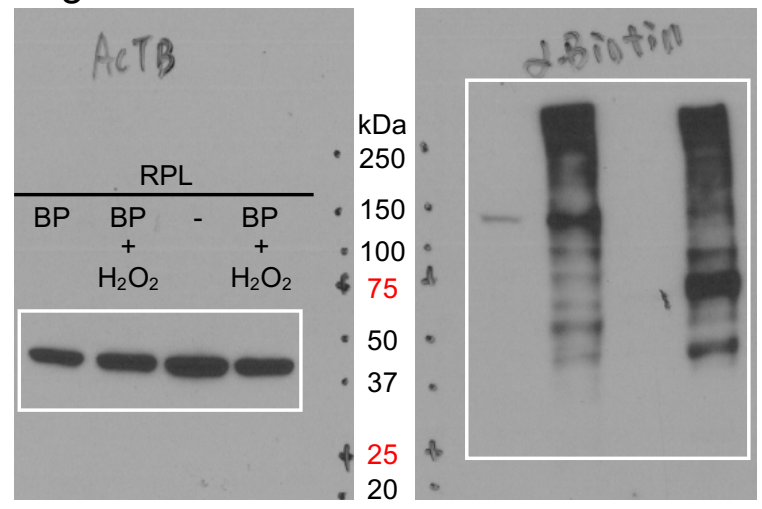

37

25 .

20 . 